\title{
Contrasting trends between species and catchments in diadromous fish counts over the last $\mathbf{3 0}$ years in France
}

\author{
Marion Legrand ${ }^{1,2, *}$, Cédric Briand ${ }^{3}$, Laëtitia Buisson ${ }^{2}$, Gwenaël Artur $^{4}$, Didier Azam ${ }^{5,17}$, \\ Aurore Baisez ${ }^{1}$, David Barracou ${ }^{6}$, Nicolas Bourré $^{7}$, Laurent Carry ${ }^{8}$, Anne-Laure Caudal ${ }^{9}$, \\ Fabien Charrier ${ }^{10}$, Jérémie Corre ${ }^{11}$, Eric Croguennec ${ }^{12}$, Sophie Der Mikaélian ${ }^{13}$, Quentin Josset ${ }^{14,17}$, \\ Laëtitia Le Gurun ${ }^{15}$, Frédéric Schaeffer ${ }^{16}$ and Pascal Laffaille ${ }^{2}$ \\ ${ }^{1}$ Loire Grands Migrateurs (LOGRAMI), 5, avenue Buffon, Orléans, France \\ 2 EcoLab, Université de Toulouse, CNRS, INP, UPS, Toulouse, France \\ ${ }^{3}$ Etablissement Public Territorial du Bassin de la Vilaine (EPTB Vilaine), Boulevard de Bretagne, La Roche-Bernard, France \\ ${ }^{4}$ Fédération de l'Ille-et-Vilaine pour la pêche et la protection du milieu aquatique, 9 Rue Louis Kérautret Botmel, Rennes, France \\ 5 Institut National de la Recherche Agronomique (INRA), UE 1036 Ecologie et Ecotoxicologie aquatique U3E, Pôle GEST'AQUA, \\ 65 rue de Saint Brieuc, Rennes, France \\ ${ }^{6}$ Migrateurs Adour, Nivelle et cours d'eau côtiers (MIGRADOUR), 74 route de la chapelle de Rousse, Gan, France \\ ${ }^{7}$ Fédération du Finistère pour la pêche et la protection du milieu aquatique, 4 allée Loeiz Herrieu, Quimper, France \\ ${ }^{8}$ Migrateurs Garonne Dordogne (MIGADO), 18 ter rue de la Garonne, Le Passage, France \\ ${ }^{9}$ Fédération du Morbihan pour la pêche et la protection du milieu aquatique, 3 Rue Marcel Dassault, Saint-Avé, France \\ ${ }^{10}$ Fish-Pass, 16 rue de la plaine, Laillé, Bretagne, France \\ 11 Normandie Grands Migrateurs (NGM), 3 rue de Bruxelles, Mondeville, France \\ 12 Syndicat Mixte d'Aménagement Touristique de l'Aulne et de l'Hyères (SMATAH), Maison éclusière de Bizernig, Chateauneuf du \\ Faou, France \\ ${ }_{13}$ Parc Naturel Régional du Marais Poitevin (PNR Marais Poitevin), 2 rue de l'Eglise, Coulon, France \\ ${ }_{14}$ Agence Française pour la Biodiversité (AFB), rue des Fontaines, 76260 Eu, France \\ ${ }^{15}$ Bretagne Grands Migrateurs (BGM), 9 rue Kérautret Botmel, Rennes, France \\ 16 Saumon Rhin (ASR), RD228 Lieu dit « la Musau », Oberschaeffolsheim, France \\ ${ }^{17}$ Management of Diadromous Fish in their Environment, AFB, INRA, Agrocampus Ouest, Université de Pau et des Pays de l'Adour \\ UPPA, Rennes, France
}

Received: 19 July 2019 / Accepted: 9 December 2019

\begin{abstract}
The decline and collapse of populations have been reported for a large range of taxa. Diadromous fishes migrate between fresh water and the sea and encounter many anthropogenic pressures during their complex life cycle. In spite of being of ecological, cultural and economic interest, diadromous fishes have been in decline for decades in many parts across the world. In this study, we investigated the change in five diadromous fish counts in France over a 30-year period using 43 monitoring stations located in 29 rivers across 18 catchments. Our hypothesis was that the counts of these species evolved in a contrasting way between catchments. We also tested the effect of five drivers potentially contributing to the observed trends: catchment, latitude, presence of commercial fisheries, improvement of ecological continuity and salmon stocking. We found contrasting trends in fish counts between species at the national scale, with some taxa increasing (Anguilla anguilla and Salmo trutta), some showing a slight increase (Salmo salar) and some decreasing (Alosa spp. and Petromyzon marinus). For each taxon, except Anguilla anguilla, we highlighted a significant catchment effect indicating contrasting trends between catchments and stations. However, we found no significant effect of catchment characteristics for any of the studied taxa.
\end{abstract}

Keywords: Diadromous fish / anadromous migration / monitoring / long-term study

\footnotetext{
*Corresponding author: tableau-salt-loire@logrami.fr
} 


\begin{abstract}
Résumé - Tendances contrastées entre les espèces et les bassins versants dans les comptages de poissons amphihalins au cours des $\mathbf{3 0}$ dernières années en France. Le déclin et l'effondrement des populations ont été signalés pour un large éventail de taxons. Les poissons amphihalins migrent entre les eaux douces et la mer, et subissent de nombreuses pressions anthropiques au cours de leur cycle de vie complexe. En dépit de leur intérêt écologique, culturel et économique, les poissons amphihalins sont en déclin depuis des décennies dans de nombreuses régions du monde. Dans cette étude, nous avons étudié l'évolution des comptages de cinq taxons amphihalins en France sur une période de 30 ans en utilisant les données de 43 stations de comptage situées dans 29 rivières et 18 bassins versants. Notre hypothèse est que les comptages de ces espèces ont évolué de manière contrastée entre les bassins versants. Nous avons également testé l'effet de cinq facteurs susceptibles de contribuer aux tendances observées : le bassin versant, la latitude, la présence de pêcheries commerciales, l'amélioration de la continuité écologique et la présence d'un programme de déversement pour le saumon. Nous avons trouvé des tendances contrastées dans les comptages de poissons entre les espèces à l'échelle nationale, certains taxons étant en augmentation (Anguilla anguilla et Salmo trutta), certains ne montrant qu'une légère augmentation (Salmo salar) et d'autres étant en déclin (Alosa spp. et Petromyzon marinus). Pour chaque taxon, à l'exception d'Anguilla anguilla, nous avons mis en évidence un effet bassin versant important indiquant des tendances contrastées entre les bassins ou les stations de comptage. Cependant, nous n'avons trouvé aucun effet significatif des caractéristiques du bassin versant pour aucun des taxons étudiés.
\end{abstract}

Mots clés : Poissons diadromes / migration anadrome / surveillance / étude à long terme

\section{Introduction}

Whatever the spatial and temporal scale, recent observations and estimates on the rate of extinction of biodiversity are alarming (Barnosky et al., 2011; Dirzo et al., 2014; Young et al., 2016; Ceballos et al., 2017; IPBES, 2019). The decline and collapse of populations have been reported for a large range of taxa: mammals (Caro, 2008; Harris et al., 2009), insects (Winfree et al., 2009; Potts et al., 2010; Hallmann et al., 2017), amphibians (Wake, 1991; Kelhart, 2007), birds (Clavero et al., 2009), fishes (Clausen and York, 2008), plants (Grime, 2002; Blomqvist et al., 2003) and corals (Hughes, 1994; Jones et al., 2004). The drivers of these declines are numerous but are mainly due to multiple stressors such as habitat loss and fragmentation (Pimm and Raven, 2000; Murphy and Romanuk, 2014), deterioration of habitat quality (Hallmann et al., 2017), legal and illegal harvesting and overexploitation (Young et al., 2016), change in land-use (Nilsson et al., 2008), climate change (Parmesan and Yohe, 2003; Root et al., 2003; Dawson et al., 2011) or species invasion (Clavero et al., 2009; Stout and Morales, 2009; Butchart et al., 2010). The decline and collapse of fish populations have been reported by numerous studies in recent decades and in different aquatic ecosystems (LobónCerviá, 2009) including oceans (e.g., Reynolds et al., 2005; Vasilakopoulos et al., 2014; Nieto et al., 2015), estuaries (e.g., Sommer et al., 2007; Rochette et al., 2010; Cloern et al., 2016), and fresh waters (e.g., Frissell, 1993; Freyhof and Brooks, 2011; Collen et al., 2014). In Europe, freshwater fishes are among the taxonomic groups having the largest number of endangered species (Nieto et al., 2015; Gozlan et al., 2019). Compared to other groups, it is the second most impacted group (i.e., about $40 \%$ of European freshwater fishes are reported threatened) after freshwater molluscs (59\%) and far ahead of amphibians (23\%) (Nieto et al., 2015).

Diadromous fishes migrate between fresh water and the sea (Myers, 1949; McDowall, 1997). Like other migratory species, their high mobility through a large diversity of habitats provides them with ecological benefits compared to nonmigratory species, including (i) growth in more productive areas, (ii) reduced predation on young stages, (iii) a better match between the environmental conditions encountered and ecological preferences, and (iv) better resilience to environmental changes (e.g., climate warming) provided that they are able to track changes at a sufficient pace (McDowall, 2001; Limburg and Waldman, 2009; Culp et al., 2017). On the other hand, diadromous fishes also face difficulties related to the large number of anthropogenic pressures they encounter during the different stages of their complex life cycle (e.g., dams, silt plugs, pollution, overfishing, flow management). In spite of being of ecological, cultural and economic interest, diadromous fishes have been in decline in many parts of the world for decades (e.g., Wolter, 2015; Waldman et al., 2016; Lambert et al., 2018). Among them, salmonids and the European eel (Anguilla anguilla) have been the focus of many studies (e.g., Dekker, 2003a; Milner et al., 2003; Bonhommeau et al., 2008; Bal, 2011; Kettle et al., 2011; Chaput, 2012; Aalto et al., 2016; Nicola et al., 2018). A diversity of management plans has been implemented to protect these species (e.g., Haapasaari and Karjalainen, 2010; Maas-Hebner et al., 2016; Almeida et al., 2018). For instance, management measures can aim at improving the quality of the environment or at reducing anthropogenic pressures (e.g., fisheries and dams) but they also include fish stocking programmes. To monitor the progress and efficiency of these management plans, count data collected continuously at video counting stations and fish traps can be used. In France, this type of data is available for a large number of counting stations located on many rivers used by migratory fishes. These data have however been underexploited to date with studies limited to a small number of stations or rivers (e.g., Kuczynski et al., 2017), while they provide valuable information for the management of these species at the national scale.

The objective of this study was to aggregate the information available about the upstream migration of diadromous fishes in France over the last 30 years in order to assess temporal trends. We investigated whether the trends are homogeneous between the different catchments or whether they are different. The catchments studied have quite different geographical (e.g., area of the catchment, latitude, slope) and 


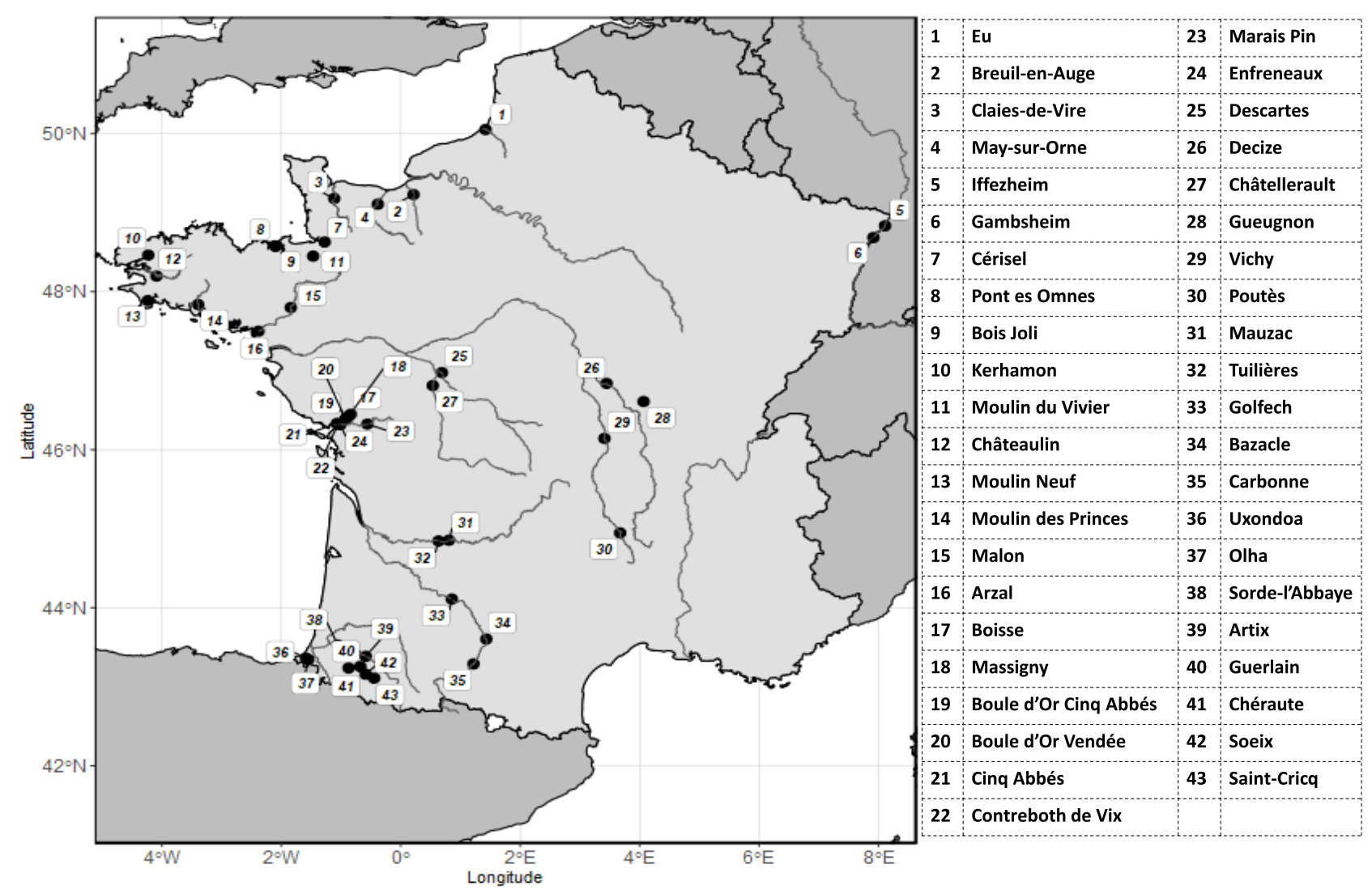

Fig. 1. Location of the 43 long-term monitoring stations. Numbers identify each station and refer to the full name in the table. Stations are ordered by mean latitude of the catchment they belong to and from north to south.

hydrological (especially water management) features. We thus hypothesise that the trend in the change in fish counts is likely to be different between the French catchments.

\section{Material and methods}

\subsection{Fish dataset}

A common toolbox for monitoring of fish migration in France has recently been developed as part of the STACOMI open source project (MIgratory fish COntrol STAtions). This toolbox comprises a database, java tools (to insert and manage data), and R packages to analyse data (Legrand et al., 2019). The data collected in the STACOMI project are numerous and consist mainly of (i) counts and dates of passage, (ii) fish characteristics, such as size, weight and age (with more or fewer details depending on the type of monitoring device, in particular trapping versus video station), (iii) observed pathologies (when the individuals are trapped and this information is recorded) and (iv) observation of the marks (e.g., PIT tags, radio transmitters, fin ablation). In this study, the counts have been compiled from 20 operators. We considered only the upstream migration because monitoring of downstream migration is mostly anecdotal. Monitoring stations can be either video counters or fish traps combined with counting of all or a substantial proportion of fishes that migrate upstream through fishways. The duration and homogeneity of sampling vary widely between stations, ranging from 1 to 35 years during the period 1983-2017. Stations with less than 10 years of monitoring have been excluded from the current analyses. Trapping and counting stations where expert judgement indicated that the efficiency had changed over time were also discarded.

Diadromous fishes are the most frequently recorded at monitoring stations. The freshwater species were removed from the dataset as they are not always included in fish counts. The same applied to migratory species that are rarely observed, either because their freshwater habitats are located mainly in the most downstream part of the rivers (Platichthys flesus) where few counting stations are present, because their abundance is low (Lampetra fluviatilis) or they are not counted at all (Liza ramada). For Anguilla anguilla, only the yellow eels were kept for analyses as the glass eel stage is counted at very few trapping stations but in very large numbers compared to the yellow eel stage.

Since the counting stations are not homogeneously located in all the catchments studied (some stations are located in the upstream parts while others are located in the downstream parts), these data do not reflect the size of the fish populations. Nevertheless, since most stations are located downstream (between 1 and $880 \mathrm{~km}$ from the sea in our dataset; median $=37 \mathrm{~km}$ ) and the analysis is global, we assume that a change in fish counts at counting stations is a good proxy of a change in population size.

After data filtering, our study included 43 monitoring stations located in 29 rivers and 18 catchments (Fig. 1; 
Appendix 1) and five diadromous taxa: Alosa spp. (because Alosa alosa and Alosa fallax cannot be distinguished through video counting), Anguilla anguilla, Petromyzon marinus, Salmo salar and Salmo trutta.

\subsection{Data analysis}

The annual fish counts in monitoring stations were assessed from 1983 to 2017 using generalised additive mixed models (GAMMs). Mixed models are ideally suited to analyse behavioural, ecological and evolutionary data when datasets have one or more levels of aggregation (Van de Pol and Wright, 2009). In addition, the use of a generalised additive model (GAM) allows description of non-linear trends in fish abundance.

First, we conducted an analysis at the national scale to assess the global trend for each of the five taxa, and then examined sub-catchment trends for each of these taxa. As the time span of monitoring data was different for each taxon, we used a separate model to predict the annual trend for each taxon. To build the five GAMMs, we transformed the annual fish counts per station into $\log ($ counts +1$)$ as some counts were zero. The potential explanatory variables were 'Year' and 'Catchment'. For all five models, the 'Station' factor was used as a random intercept, and a smooth effect was used for 'Year'. To assess whether this annual trend was national (i.e., the whole of France) or regional (i.e., different between catchments), two different assumptions were tested: (i) a different trend for each catchment (model 1), and (ii) a single trend for all catchments (model 2). To choose the better of the two models, we used the Akaike Information Criterion (AIC) (Akaike, 1974) and a Chi-square $\left(\chi^{2}\right)$ test provided by the $\mathrm{R}$ package 'itsadug' (Van Rij et al., 2017). This allows comparison of two models on the basis of the minimised smoothing parameter selection score specified in the model, and to perform a $\chi^{2}$ test on the difference in scores and the difference in degrees of freedom (Van Rij, 2016). As the series recorded at the stations were of unequal length, a time trend was rebuilt for the whole of France by keeping the trend constant outside the period of observation. Given the data available, the national trend was built up by summing the predictions only at the most downstream station of a given river ( $37 \%$ of the rivers had more than one monitoring station). Indeed, the counts at a station located upstream from another station were considered as duplicates and underestimated the total number of migrating fishes present in the river (i.e., fish can be counted at the downstream station but not at the upstream one). However, they were not removed from the other analyses as those upstream stations could cover a longer time period than the downstream stations.

To test for monotonous temporal trends in the change in annual fish counts, we performed a meta-analysis of MannKendall trend statistics $(S)$ with fixed-effect model computed at each station (Daufresne and Boët, 2007; Maire et al., 2019). We first corrected the variances of S for temporal autocorrelation (Hamed and Rao, 1998). We used Mann-Kendall statistics, as they allow to test whether there is a general monotonous trend (without the link necessarily being linear) over the period considered. This method, while less precise than trends highlighted by GAMMs, allows summarising of the results at the level of the stations as well as of the catchments. The meta-analyses were conducted using the 'metafor' package in R (Viechtbauer, 2010). We specified a weight that corresponds to the sum of the fish counted for each taxon at each station in order to account for the importance of a station in terms of annual counts or duration (both would result in larger counts). To test whether detected trends in the number of fish counted could be related to catchment management (e.g., Romakkaniemi et al., 2003; de Eyto et al., 2016), we collected information on (i) the presence or absence of a commercial fishery downstream of each station, (ii) improvements in ecological continuity (i.e., river connectivity) downstream from each station for the upstream migration, and (iii) the presence of a stocking programme influencing fish counts at monitoring stations (which applies to salmon only) (Appendix 1). The information was collected for each monitoring station and was not species-dependent except in the presence of a stocking programme (i.e., salmon only). For each station, we also recorded the latitude (Appendix 1), as numerous studies have documented a northward shift in the distribution of many taxa due to recent climate change (Parmesan and Yohe, 2003; Comte and Grenouillet, 2015; Horreo et al., 2018). We therefore tested the hypothesis that southern stations have suffered a more severe decline in fish counts over the last decades than have northern stations. We included the three management variables, the latitude and the catchment as a matrix of moderators in the meta-analysis.

\section{Results}

\subsection{Change in fish counts in France}

For the five GAMMs built (i.e., one for each taxon), the best model always included multiple smooth effect on year with a different trend per catchment (Tab. 1). GAMMs including a catchment effect performed better than those without $\left(\chi^{2}(142)=732.126, p<0.001\right)$. Depending on taxon, the best model explained between $73.7 \%$ (Petromyzon marinus) and $87.9 \%$ (Salmo trutta) of the variation in the data (Appendices 2-6).

Given this result, annual fish counts of each taxon were assessed at the national scale using reconstructed predictions of the five GAMMs. The trends in annual fish counts were different between taxa (Fig. 2). Alosa spp. was the taxon whose counts changed the most during the period. This taxon showed a clear trend towards decline in France (i.e., a percentage change over time between the first and last five monitoring years of $-96.4 \%$ ). The annual counts of Petromyzon marinus have also declined over time, but in a lesser extent than for Alosa spp. (i.e., a percentage change over time of $-80.3 \%$ ). Salmo salar showed fluctuations in counts between years but no clear trend over the studied period in France (i.e., a percentage change over time of 9.2\%). Finally, the counts of Anguilla anguilla and Salmo trutta increased (i.e., a percentage change over time of $55.4 \%$ and $72 \%$, respectively), especially after 2005 . The results for all five taxa showed very large confidence intervals (Fig. 2) indicating a great variability between catchments and stations, except during the last 10 years for Alosa spp. where the confidence interval is thin. 
Table 1. Comparison between GAMM with single smooth effect (SSE) vs. GAMM with multiple smooth effect (MSE) on year using catchment for each taxon. * indicates the best model. Scores are fREML scores. EDF: estimated degree of freedom. Diff.: difference between scores of the models. DF: difference between EDF of the models. AIC diff.: difference in the Akaike Information Criterion (AIC) between models. ** indicates the model with the lowest AIC. $P=$ probability of $\chi^{2}$ test.

\begin{tabular}{|c|c|c|c|c|c|c|c|}
\hline Taxon & Model & Scores & EDF & Diff. & $\mathrm{DF}$ & AIC diff. & $P$ \\
\hline \multirow{2}{*}{ Alosa sp. } & MSE $^{*}$ & 535.2175 & 37 & \multirow[t]{2}{*}{88.141} & \multirow[t]{2}{*}{22} & \multirow[t]{2}{*}{$174.62^{* *}$} & \multirow[t]{2}{*}{$<0.001$} \\
\hline & SSE & 623.3582 & 15 & & & & \\
\hline \multirow{2}{*}{ Anguilla anguilla } & MSE $^{*}$ & 967.3409 & 43 & \multirow[t]{2}{*}{39.396} & \multirow[t]{2}{*}{26} & \multirow[t]{2}{*}{$71.05^{* *}$} & \multirow[t]{2}{*}{$<0.001$} \\
\hline & $\mathrm{SSE}$ & 1006.7365 & 17 & & & & \\
\hline \multirow{2}{*}{ Petromyzon marinus } & MSE $^{*}$ & 601.3856 & 31 & \multirow[t]{2}{*}{53.061} & \multirow[t]{2}{*}{18} & \multirow[t]{2}{*}{$92.43^{* *}$} & \multirow[t]{2}{*}{$<0.001$} \\
\hline & SSE & 654.4463 & 13 & & & & \\
\hline \multirow{2}{*}{ Salmo salar } & MSE $^{*}$ & 675.3592 & 46 & \multirow[t]{2}{*}{35.140} & \multirow[t]{2}{*}{28} & \multirow[t]{2}{*}{$85.47^{* *}$} & \multirow[t]{2}{*}{$<0.001$} \\
\hline & SSE & 710.4989 & 18 & & & & \\
\hline \multirow{2}{*}{ Salmo trutta } & MSE $^{*}$ & 593.0208 & 46 & \multirow[t]{2}{*}{80.553} & \multirow[t]{2}{*}{28} & \multirow[t]{2}{*}{$171.83^{* *}$} & \multirow[t]{2}{*}{$<0.001$} \\
\hline & SSE & 673.5735 & 18 & & & & \\
\hline
\end{tabular}

\subsection{Change in fish counts per catchment and monitoring station}

In the meta-analysis, the only significant moderator was the catchment for Alosa spp., Salmo trutta, Salmo salar and Petromyzon marinus. The other moderators (i.e., latitude, presence of fishing, improvements in ecological continuity and salmon stocking) were not significant. For Anguilla anguilla, none of the moderators was significant.

Alosa spp. showed the largest number of stations (10/19, $53 \%$ ) with a significant trend and also the largest number of significant decreasing trends $(8 / 19,42 \%)$ (Fig. 3). At the national scale, we observed a significant decreasing trend. At the catchment level, a significant decreasing trend was found only for the Loire and Garonne-Dordogne catchments.

About 35\% (11/31) of stations where Anguilla anguilla was monitored experienced a significant trend (Fig. 4). Among them, there was a greater number of decreasing $(7 / 31,22 \%)$ than increasing $(4 / 31,13 \%)$ trends. Nevertheless, the station with the largest counts (Arzal) showed a significant upward trend. This station contributes strongly to the trend at the national scale, which is an increasing but non-significant trend.

For Petromyzon marinus, 33\% (6/18) of stations showed a significant trend (Fig. 5). Half of the six stations (17\%) showed an increasing trend, while the other half experienced a decreasing trend. Several catchments located in northern France (Oir, Vilaine, Vire, Aulne) showed a significant increase, while the Loire catchment showed a significant decrease. At the national scale, we observed a significant decreasing trend.

For Salmo salar, 34\% (10/29) of stations showed a significant trend (Fig. 6). The number of stations showing a significant upward trend was slightly higher $(6 / 29,20 \%)$ than the number of stations with a significant downward trend $(4 / 29,14 \%)$. The Nivelle catchment showed a significant decrease, while the Loire and Adour catchments showed a significant increase. At the national scale, we observed a slight but significant increase.

Lastly, for Salmo trutta, 41\% (11/27) of stations showed a significant trend (Fig. 7), about half with an increase $(6 / 27$, $22 \%)$ and the other half with a decrease $(5 / 27,19 \%)$. The Garonne-Dordogne and Oir catchments showed a significant decrease, while the Adour and Bresle catchments showed a significant increase. At the national scale, we observed a significant increase.

\section{Discussion}

The implementation and compilation of a national database has allowed us to compile an original dataset of millions of fish passages at counting stations in metropolitan France. This dataset was used to test whether, during the last 30 years, diadromous fishes have experienced an overall decline in France, as reported elsewhere in the world (Dirzo et al., 2014; Young et al., 2016). In order to analyse these data, we had to make the assumption that the efficiency of the counting stations had not changed over time. We know that this is not necessarily true, due to successive equipment and technological improvements in monitoring. To account for this potential bias, we have carefully selected the stations by systematically excluding those that have undergone major changes according to expert judgements.

Our results show that changes in fish counts over the last 30 years in France depend on fish taxa and that an overall decline in all populations and species has not occurred, as we expected. Fish counts for Alosa spp. and Petromyzon marinus have decreased at the national scale, while those for Anguilla anguilla and Salmo trutta have increased. Fish counts for Salmo salar have remained stable with only a slight increase. Likewise, we highlighted a significant variability between the catchments and the stations, indicating that there is not a massive decline of diadromous fishes in France, but there are contrasting situations. Even for Alosa spp. (which is the taxon with the greatest decline over the study period), we noted that fish counts in two stations $(10.5 \%)$ had increased significantly.

Shad populations, especially those of Alosa alosa, have declined severely across Europe over the past century (Aprahamian et al., 2003; Baglinière et al., 2003; Nachón et al., 2015). Alosa alosa was originally distributed from Norway (north) to Morocco (south) and from the coasts of Germany (east) to the British Isles (west), while the distribution of Alosa fallax, although morphologicaly very similar, extended further north (to Iceland) and further east 

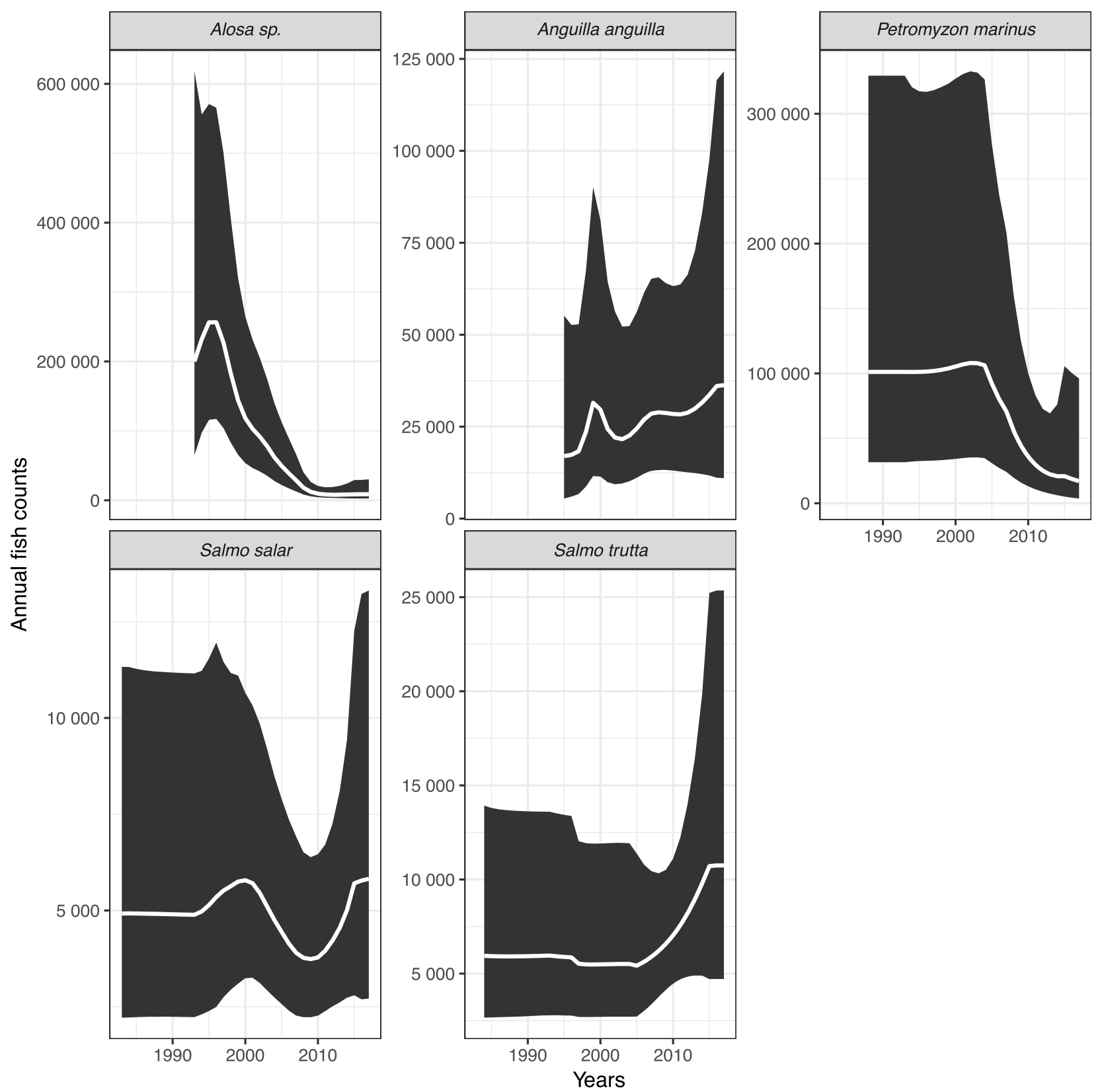

Fig. 2. Change in annual fish counts of the five diadromous taxa summed at the national scale. Black curves are the mean change in annual counts and grey ribbons the $95 \%$ confidence intervals. Note that the annual fish counts on the $y$-axis are different between taxa.

(to Scandinavia and the Baltic Sea) (Baglinière and Ellie, 2000; ICES, 2015; Lambert et al., 2018). Currently, the northern limit for Alosa alosa is the Vire catchment in Normandy (France) and the southern limit is the Minho catchment, located at the boundary between Portugal and Spain (Mota et al., 2016), while the northern limit for Alosa fallax is the Nemunas river (Lithuania) and the southern limit is the Guadalquivir river (Spain) (ICES, 2015). Baglinière et al. (2003) reported that for the period 1978-1998, about $94 \%$ of the total landings of nominal catches of shad were in France, with $89 \%$ from the Garonne-Dordogne catchment alone. At the end of the 20th century the Alosa alosa population in the Garonne-Dordogne was the largest in
Europe, but during the first decade of the 21st century, catches declined dramatically (Rougier et al., 2012). Our results are consistent with this finding, emphasising the importance of the Garonne-Dordogne population compared to the other French populations in terms of fish counted at monitoring stations, and by highlighting the severe decline of this population. At the national scale, the population of Garonne-Dordogne was therefore by far the most important, and the collapse of this population contributes to the observed decline of shad at the national level. Reasons for this collapse are numerous and remain uncertain, but Rougier et al. (2012) hypothesise a past high mortality in the estuary (due to fisheries) combined with a demographic Allee effect (depensation in fish stock 


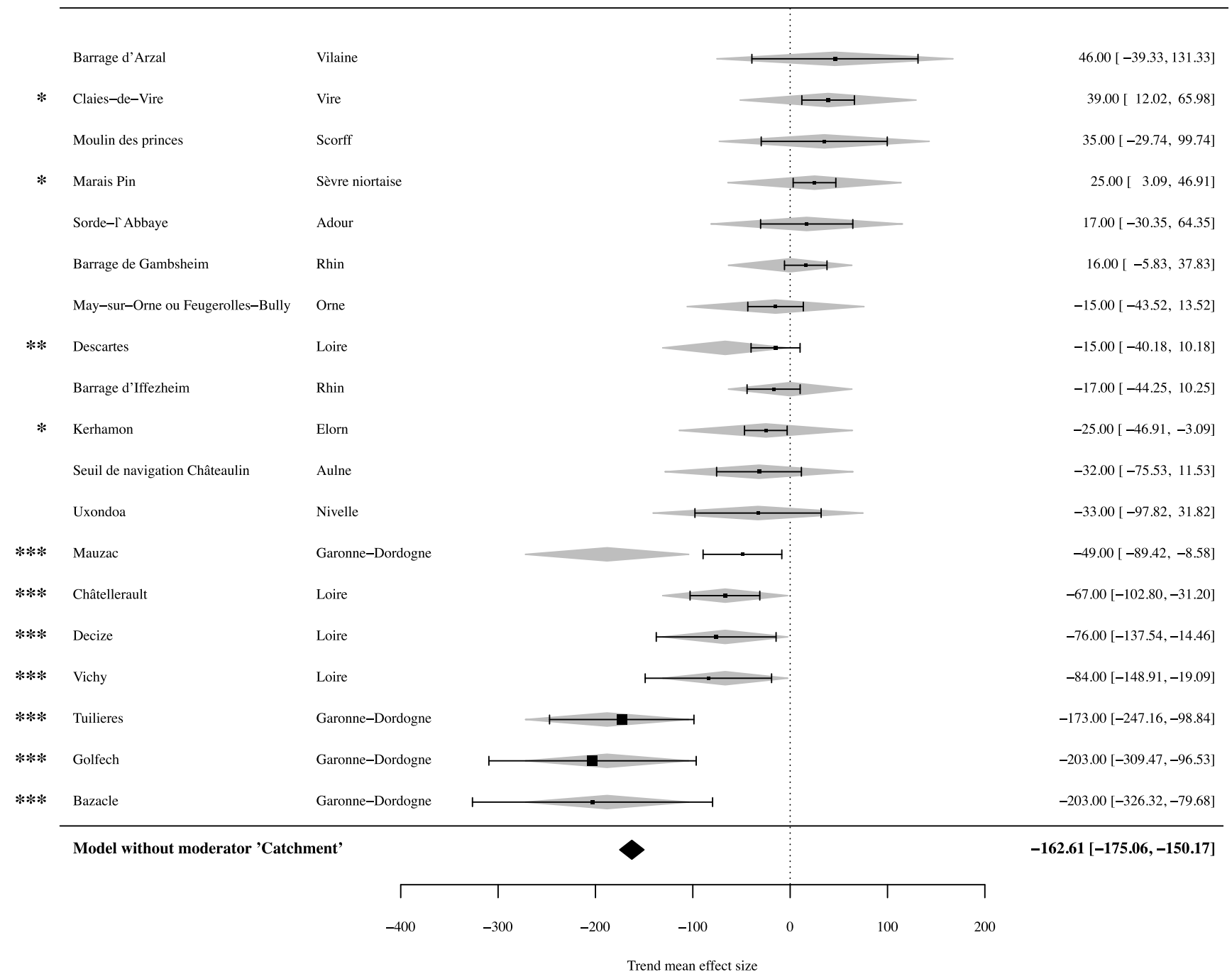

Fig. 3. Trend in annual fish counts of Alosa spp. (black squares) for each monitoring station and $95 \%$ confidence intervals (whiskers). The size of the black squares is proportional to the weight of each station (i.e., the sum of counts over the study period) in the analysis. When the black square is located on the left side of the zero vertical line, the trend is declining. When it is located on the right side, the trend is increasing. Grey diamonds display the effect of the moderator 'Catchment'. The black diamond at the bottom indicates the overall mean effect size for all the stations; * highlights a significant trend for the station (when the whiskers do not intersect the zero vertical line); ** highlights a significant trend for the catchment (when the grey diamond does not intersect the zero vertical line), but not for the station; *** highlights a significant trend for both the station and the catchment.

productivity - Myers et al., 1995; Liermann and Hilborn, 2001; Sun, 2016), possibly in synergy with environmental changes. In addition, the trend reported at the national scale also highlights the collapse of shad counts in France with a very thin confidence interval over the last few years, indicating little contrast between the different counting stations. Overall, we found that only two stations showed a significant positive trend for shad: (i) Claies-de-Vire on the Vire river, and (ii) Marais Pin on the Sèvre Niortaise river. On the Vire river, this trend can be explained by an ambitious programme of river connectivity restoration and by an improvement in water quality due to an improvement of the water treatment plants in the catchment (Goulmy, 2016). These efforts seem to benefit all diadromous fish species, with increasing trends found (significant or not) for all species counted (Figs. 3, 5-7). At the Marais Pin station, again the increasing trend can be explained by a recent improvement in river connectivity. Our nationallevel shad analysis points to the onset of declining counts around 1995, several years before the decline was reported in fisheries data (Rougier et al., 2012). This may be due to the position of the counting stations being upstream of the most important fisheries, which are mainly located in estuaries or in 
M. Legrand et al.: Knowl. Manag. Aquat. Ecosyst. 2020, 421, 7

Meta-analysis for Anguilla anguilla

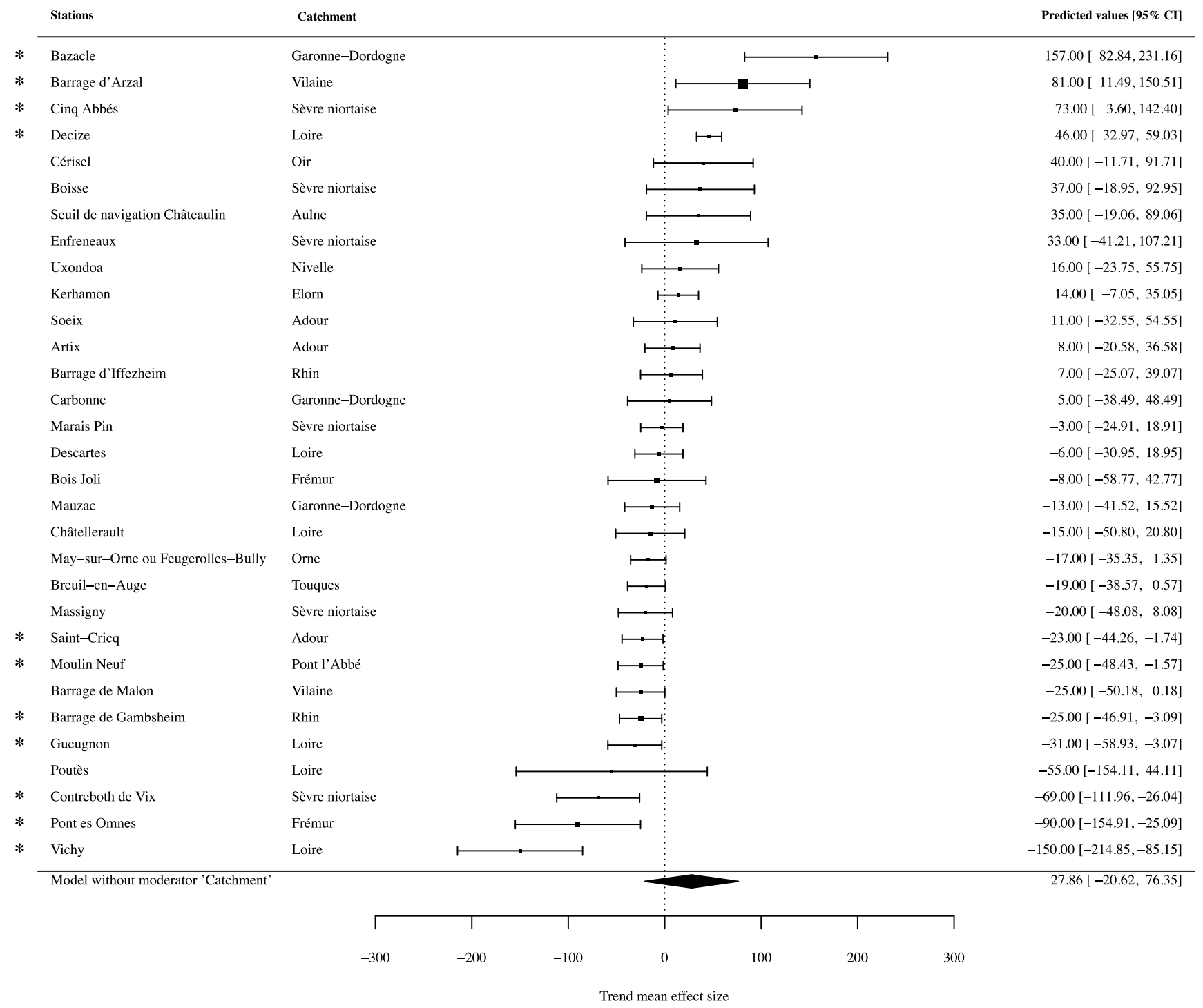

Fig. 4. Trend in annual fish counts of Anguilla anguilla (black squares) for each monitoring station and $95 \%$ confidence intervals (whiskers). The size of the black squares is proportional to the weight of each station (i.e., the sum of counts over the study period). When the black square is located on the left side of the zero vertical line, the trend is declining. When it is located on the right side, the trend is increasing. None of the five moderators tested in the model was significant. The black diamond at the bottom indicates the overall trend mean effect size for all the stations; * highlights a significant trend for the station (when the whiskers do not intersect the zero vertical line).

the most downstream parts of the rivers. The counting stations would thus report an earlier decline due to a gradual erosion of the population with fewer individuals migrating upstream. This finding thus stresses the importance of counting stations that can provide early signals of a developing trend (either a decline or an increase).

In this study we analysed the trend in counts only for the yellow eel stage of Anguilla anguilla, and not glass eels. Using GAMM analyses, we highlighted a trend towards increasing counts for this life stage. However, we found no significant trend in the meta-analyses for this species at the national level. Moreover, the observed increase in eel counts (found in the GAMM analyses) has to be mitigated by the short length of the time series (after 1995). Indeed, in Europe, it is well documented that the recruitment of eels has greatly decreased since the 1980s (e.g., Dekker, 2003b, Bonhommeau et al., 2008; Kettle et al., 2011). Consequently, the 1.5-fold increase in yellow eel counts found after 1995 has to be considered in the context of a $90 \%$ decline in European eel recruitment in Europe (Dekker, 2003b). In addition, our observed trend is not consistent with that of the Eel Density Analysis (EDA) model (Briand et al., 2018), derived from the analysis of yellow eel abundance at electrofishing stations. In contrast, this model reported a decreasing trend for all size classes except for the lowest size class $(<150 \mathrm{~mm})$ for which an increase has been observed, but only since 2011. Stations located in the Biscay 
M. Legrand et al.: Knowl. Manag. Aquat. Ecosyst. 2020, 421, 7

Meta-analysis for Petromyzon marinus

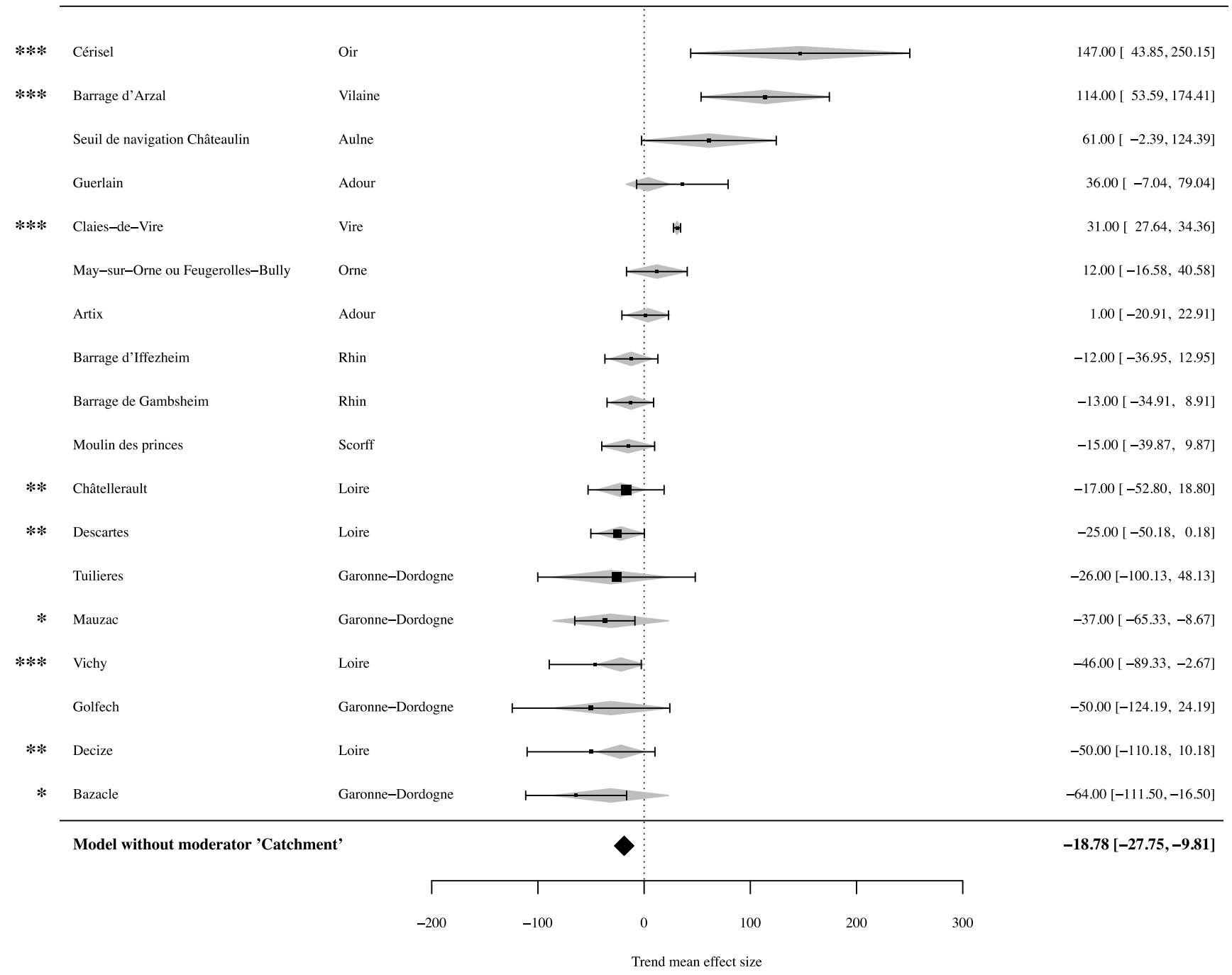

Fig. 5. Trend in annual counts of Petromyzon marinus (black squares) for each monitoring station and $95 \%$ confidence intervals (whiskers). The size of the black squares is proportional to the weight of each station (i.e., the sum of counts over the study period). When the black square is located on the left side of the zero vertical line, the trend is declining. When it is located on the right side, the trend is increasing. Grey diamonds display the effect of the moderator 'Catchment'. The black diamond at the bottom indicates the overall mean effect size for all the stations; * highlights a significant trend for the station (when the whiskers do not intersect the zero vertical line); ** highlights a significant trend for the catchment (when the grey diamonds do not intersect the zero vertical line), but not for the station; *** highlights a significant trend for both the station and the catchment.

area are highly influenced by the fishing pressure on glass eel (Briand et al., 2003, Briand, 2009). The recent decrease in the fish mortality observed in France (Plan National de Gestion de l'Anguille - Anonyme, 2018) combined with the recent increase in recruitment is a possible explanation for the observed trend. Moreover, further upstream in the catchments, the eel counts also integrate the effect of management measures (i.e., restoring the ecological continuity or stocking programmes). However, few eels have been counted in these upstream stations compared to the most downstream stations (e.g., Ibbotson et al., 2002, Lasne and Laffaille, 2008a). Thus, when log-transformed in the model prediction, they have a negligible influence on the rebuilding of national count trends. This explains why the majority of stations display a negative trend in the meta-analysis while the general trend reconstructed at the national level shows an increase. The eel population of Vilaine dominates the trend in numbers, and part of the increase observed before 2000 is due to large escapes from the fishery in 1996 and 1998 (Briand et al., 2003). Later increases in yellow eel counts correspond to the large number of glass eel escaping the fishery and ascending the trap. Numbers collected at monitoring stations in fact reflect the 
M. Legrand et al.: Knowl. Manag. Aquat. Ecosyst. 2020, 421, 7

Meta-analysis for Salmo salar

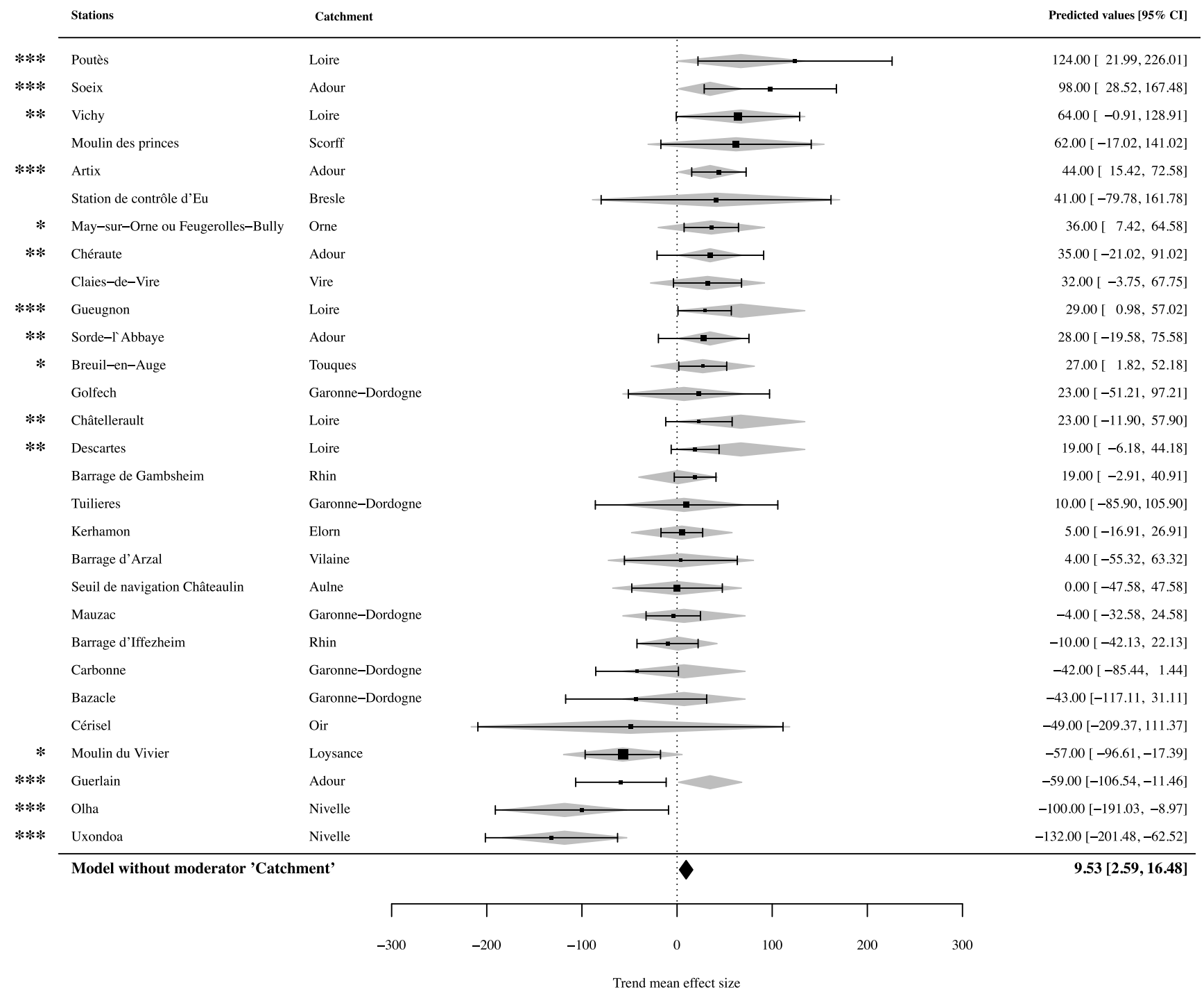

Fig. 6. Trend in annual fish counts of Salmo salar (black squares) for each monitoring station and $95 \%$ confidence intervals (whiskers). The size of the black squares is proportional to the weight of each station (i.e., the sum of counts over the study period). When the black square is located on the left side of the zero vertical line, the trend is declining. When it is located on the right side, the trend is increasing. Grey diamonds display the effect of the moderator 'Catchment'. The black diamond at the bottom indicates the overall trend mean effect size for all the stations; * highlights a significant trend for the station (when the whiskers do not intersect the zero vertical line); ** highlights a significant trend for the catchment (when the grey diamond does not intersect the zero vertical line), but not for the station; *** highlights a significant trend for both the station and the catchment.

fractal nature of the stock (Dekker, 2000) where the recruitment trend, mostly common to all basins, is further influenced by local catchment factors. As such, trends derived from counting stations are probably difficult to interpret at a higher level (e.g., national scale). However, the fact that some stations located upstream of the largest glass eel fisheries (Bazacle in the Garonne-Dordogne catchment, Arzal in the Vilaine catchment and Cinq Abbés in the Sèvre Niortaise catchment) are actually showing a clear increasing trend could reflect positively on the management actions according to the European eel plan and its local adaptations. Nevertheless, the trend is not significant for all the stations of these three catchments, probably because we did not use glass eel counts. In contrast, stations such as the Frémur, located in a small stream in the north of Brittany, do show a clear decreasing trend and are probably much more representative of the general decline in glass eel recruitment observed before 2011 (Acou et al., 2009). Moreover, catchment colonisation is mostly by glass eels and young yellow eels. Glass eels are only present close to the tidal limit (Gascuel, 1986; Laffaille et al., 2007). In those places, they dominate the station counts. Further upstream, the average size will increase with the distance 
M. Legrand et al.: Knowl. Manag. Aquat. Ecosyst. 2020, 421, 7

Meta-analysis for Salmo trutta

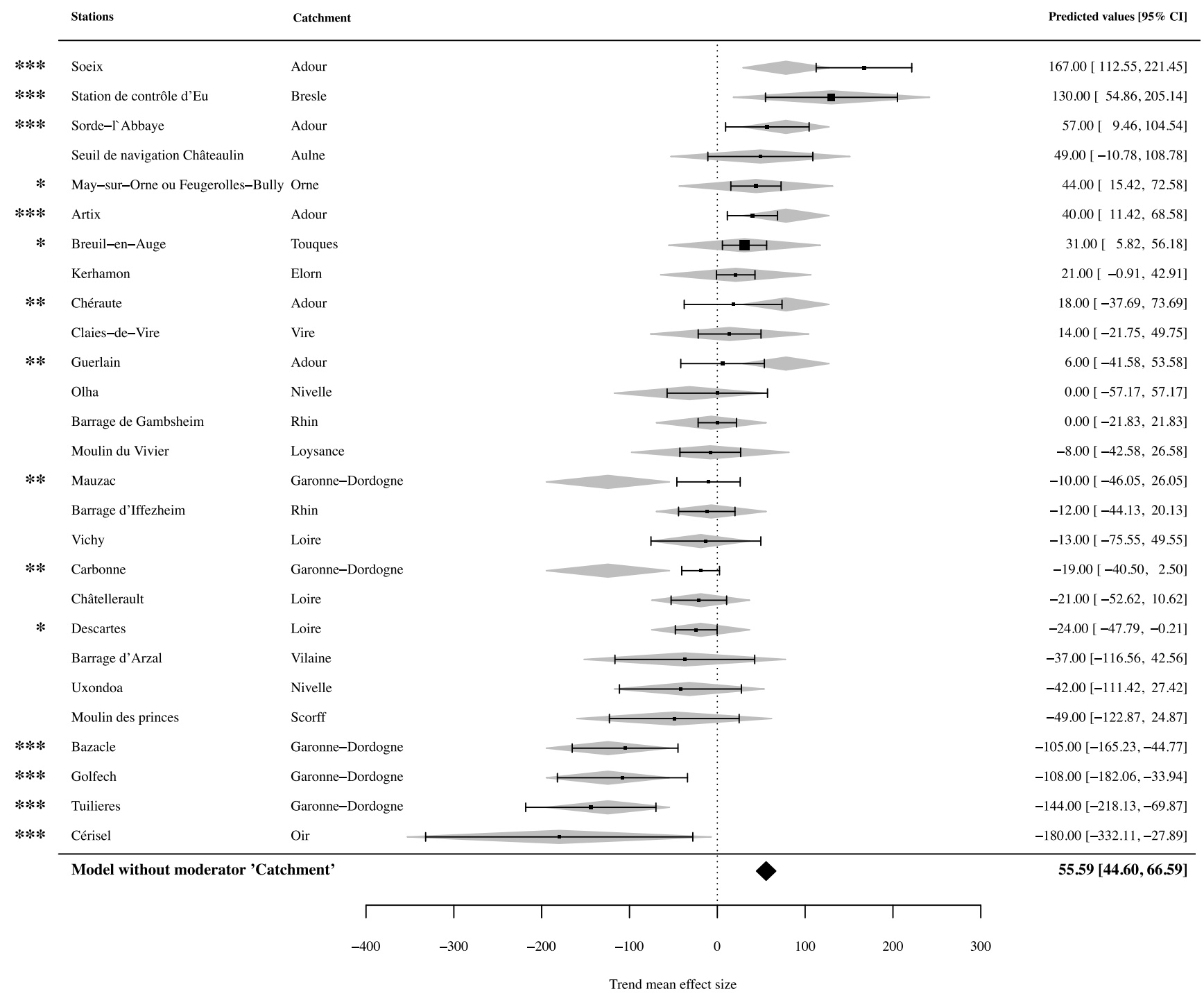

Fig. 7. Trend in annual fish counts of Salmo trutta (black squares) for each monitoring station and $95 \%$ confidence intervals (whiskers). The size of the black squares is proportional to the weight of each station (i.e., the sum of counts over the study period). When the black square is located on the left side of the zero vertical line, the trend is declining. When it is located on the right side, the trend is increasing. Grey diamonds display the effect of the moderator 'Catchment'. The black diamond at the bottom indicates the overall trend mean effect size for all the stations; * highlights a significant trend for the station (when the whiskers do not intersect the zero vertical line); ** highlights a significant trend for the catchment (when the grey diamonds do not intersect the zero vertical line), but not for the station; *** highlights a significant trend for both the station and the catchment. When black squares are located on the left side of the zero vertical line, the trend is declining. When they are located on the right side, the trend is increasing.

from the sea (Barak and Mason, 1992), as historically glass eel transport has been limited in France. Thus, our analysis of yellow eel migration at monitoring stations provides an assessment of the early changes in the colonisation phase of the eel, while electrofishing results are more related to the standing stock in the basins (e.g., Lasne and Laffaille, 2008a, 2008b).

Counts of Petromyzon marinus have decreased throughout France over the last 30 years, although we observed as many stations with a significant upward trend as with a downward trend. However, the four stations with the largest sea lamprey counts are in decline (Châtellerault and Descartes in the Loire catchment and Tuillères and Golfech in the Garonne-Dordogne catchment). The decreasing trend in sea lamprey numbers in France found in this study is consistent with other studies highlighting a decline of some populations, such as the Iberian (Mota et al., 2016). Like shad, the decrease in counts is detected earlier at counting stations (around 2005) than in fisheries, where it has not yet been detected. In contrast, in the Garonne-Dordogne catchment, which is the top-ranked catchment for the sea lamprey population, captures by 
fisheries have increased over the period 1990-2005 (Beaulaton et al., 2008).

Several studies have documented that Salmo salar stocks have declined over recent decades, especially in the southern parts of the salmon range (Parrish et al., 1998; Brun, 2011; ICES, 2018). In the North Atlantic, the decline in commercial salmon catches occurred around the mid-1970s (Parrish et al., 1998). In France, the range of salmon has been severely reduced with the loss of populations in large catchments such as the Rhine, Seine and Garonne-Dordogne (Bal, 2011). Currently, it is estimated that only about 30 populations are viable, located mainly in Brittany, Lower Normandy and southwestern France (Thibault, 1994; Bal, 2011). The data analysed in this study started in the 1980s, after the onset of the decline of Salmo salar stocks. Overall, we found a slight increasing trend over the last 30 years. However, the Nivelle catchment (located in southwestern France) seems to have suffered a significant decreasing trend, consistent with the decline reported in this catchment by Brun (2011) for the last 5 years of the 1984-2007 period. Among the 29 stations considered for Salmo salar in this study, 19 have stocking programmes that may have influenced the counts. We found that $12(63 \%)$ of the stations with a stocking programme showed a tendency towards an increase, but the trend is significant for only four stations. Nevertheless, the fact that $65 \%$ of the studied stations are located in rivers where a stocking programme is implemented probably explains the slight general upward trend in salmon populations, concomitantly with the reported contraction of its range in France.

Although the decline in Salmo trutta stocks and fisheries has been documented in many places, the situation is more variable for this species, with populations that seem to increase in some regions and collapse in others (Mota et al., 2016; Almeida et al., 2018). Using electrofishing data, Poulet et al., (2011) found a general decrease in the occurrence and abundance of the juveniles of Salmo trutta in France from 1990 to 2009. These results seem consistent with other studies (using observed or predictive models) in France and Switzerland (e.g., Borsuk et al., 2006; Zimmerli et al., 2007; Buisson et al., 2008). In contrast, our results show stable annual fish counts between 1985 and 2005 and an increase after 2005. The Garonne-Dordogne and Oir were the only catchments with a significant decreasing trend. Using electrofishing data, Bergerot and Cattanéo (2016) found a positive relationship between the density of Salmo trutta juveniles and river size in France. This could explain the opposing trends highlighted by studies using electrofishing in small to medium streams and those using counting stations in rather large rivers. In addition, juveniles were considered by Poulet et al. (2011), while only adults were counted in this study.

Interestingly, in our study we found trends in fish counts that do not always match the reported trends using fisheries data. For instance, we found a decreasing trend in the main populations of Alosa spp. and Petromyzon marinus several years before the reported decreases in fisheries data (Beaulaton et al., 2008; Rougier et al., 2012). Fisheries data are used extensively by fisheries managers for population assessment, as long-term fisheries exist in many places (Lucas and Baras, 2000). Nevertheless, these data are known to have some biases. In particular, catchability may vary between times of the day, seasons, gear used, efficiency of the fisheries (linked to fishermens' experience and technology used) and dynamics of the population, but also environmental factors (Lucas and Baras, 2000; Maunder et al., 2006). Moreover, fisheries data can be affected by underreporting that can vary over place and time (Maunder et al., 2006; Zeller et al., 2011; Coll et al., 2014). Data collected at counting stations also have some biases, the most important being changes in the attractivity of the fish facility due to environmental conditions and/or lack of maintenance. Because the largest fisheries are often located in marine or estuarine areas and counting stations are located in the rivers (between 1 and $880 \mathrm{~km}$ from the sea in our dataset; median $=37 \mathrm{~km}$ ), data from counting stations are affected by additional factors as compared to fisheries data from estuaries or marine environments (e.g., predation in the river, barriers to fish migration, local environmental conditions). Considering the potential biases of the two types of data and the fact that they potentially do not relate to the same fraction of a population (especially when the counting stations are located far from the fisheries), we emphasise the importance of using various sources of data to provide a more robust assessment of the trends in diadromous fishes population.

In this study, we highlighted a strong catchment effect for each taxon, except for Anguilla anguilla. This effect could indicate that anadromous taxa are structured in populations that are different between catchments. The European eel is widely recognised as a single panmictic population (Dannewitz et al., 2005; Palm et al., 2009; ICES, 2015), with the exception of a few studies reporting evidence for a weak but significant population structure (Wirth and Bernatchez, 2003; Maes and Volckaert, 2002). The well-known panmixia in this species seems the best explanation for this lack of catchment effect. Homing (i.e., the return of fish to their natal river) and straying (i.e., the migration of individuals to nonnatal sites to reproduce) behaviours are two fundamental lifehistory traits of most anadromous fishes (Martin et al., 2015). While straying allows for colonisation of new habitats, maintenance of genetic diversity, mitigation of spatial and temporal variation in habitat quality (Keefer and Caudill, 2014) and result in metapopulation dynamics (Randon et al., 2018), homing leads to local adaptation of populations (McDowall, 2008), providing fitness benefits (Martin et al., 2015). The degree of fidelity for homing varies between species (Melvin et al., 1986). It is rather high for salmonids (e.g., King et al., 2001; McDowall, 2001; Petersson, 2015), ranging from very precise (i.e., within metres) to quite large (i.e., catchment) (Keefer and Caudill, 2014). In American shad (Alosa sapidissima), a high degree of homing has also been documented (e.g., Melvin et al., 1986; Walther and Thorrold, 2008; Hasselman et al., 2010), while the pattern is less clear for Alosa fallax and Alosa alosa over substantial parts of their geographic range (Jolly et al., 2012; Martin et al., 2015). Yet, Randon et al. (2018) found that Alosa alosa populations in France are relatively connected, at least within catchments. The catchment effect highlighted in this study for Salmo salar, Salmo trutta and Alosa spp. seems therefore consistent with the homing behaviour and population structure. Regarding sea lamprey, evidence for lack of homing has been highlighted in several studies (e.g., Bergstedt and Seelye, 1995; Bryan et al., 2005; Waldman et al., 2008; Spice et al., 2012). However, the significant catchment effect highlighted in our study seems consistent with the homing behaviour of the species. However, 
the catchment effect could also reflect significant differences in management (e.g., ecological continuity, fisheries) regardless of the homing behaviour of species.

We tested three factors expected to have influences on annual fish counts at monitoring stations (i.e., commercial fisheries, improvements in ecological continuity and salmon stocking programmes). None of these factors were significant in our analysis. This unexpected finding does not necessarily reflect a lack of effect of these factors but rather a lack of accurate data. We were indeed unable to provide quantitative information to describe these factors. For example, catches can vary greatly between fisheries. For instance, catches of Petromyzon marinus in France vary from 8.5 tonnes in the Adour catchment to 58 and 72 tonnes in the Loire and Garonne-Dordogne catchments, respectively (Beaulaton et al., 2008). Similarly, the numbers of salmon stocked into rivers vary between catchments and between years within a catchment (Dumas and Prouzet, 1994; Perrier et al., 2013). Moreover, other factors can play a role in the trend of annual fish counts, such as chemical water quality, flow or water temperature, which can change the attractivity of a fish passage facility (Brodeur et al., 2007; Piper et al., 2012), the swimming capacity of the fish (Brett, 1967; Haro et al., 2004) and survival (Baisez et al., 2011; Fenkes et al., 2016). Thus, the fact that we were not able to explain the trends observed using the studied factors can be related to (i) a lack of precision of these factors (presence/absence instead of finer quantification), (ii) untested factors that may have influenced the counts (e.g., river flow, temperature), and (iii) the fact that the influence on the counts by the factors is probably multifactorial with synergistic, additive or even antagonistic species responses between the different factors.

We also tested whether the latitude of the stations influenced the fish counts observed. Several studies have highlighted a northward shift in the range of many taxa (e.g., Parmesan and Yohe, 2003; Lassalle and Rochard, 2009). We thus hypothesised that the fish counts in the southern stations would have decreased more than in the northern ones, especially for cold-water species (e.g., salmonids). However, this factor was not significant for any taxa, indicating either that we have not yet observed in France a shift in the distribution of these taxa, or that this change occurs at a larger temporal and/or geographical scale (e.g., the European scale; Lassalle and Rochard, 2009).

Our results provide a multi-scale analysis of the change in annual diadromous fish counts in France from data usually used at a local geographical scale. In France, as many rivers have counting stations, this monitoring tool allows assessment of trends in diadromous fish at large geographical scale (e.g., France). This is particularly useful, as management of biodiversity is needed at multiple scales, from local to international levels (Watson, 2005; Heller and Zavaleta, 2009), involving different public policies, such as in restoring connectivity (e.g., Annex V of the European Water Framework Directive (DCE) (directive 2000/60); French law $\mathrm{n}^{\circ}$ 2006-1772, in particular with article L214-17); in water quality (e.g., European Water Framework Directive (directive 2000/60)); or in the management of species (e.g., European regulation on eel (EC 1100/2007)). In France, all these policies are defined and implemented at a catchment scale, but we still need a national assessment, as diadromous species are used as indicators of the success of some of these policies (when they are not the target). At the catchment scale, data at counting stations are also interesting, as they allow comparisons of trends in a catchment with the national trend. This can be a powerful tool to encourage management actions if a decline is more pronounced in a particular catchment than at the national level. Furthermore, information on the spatial extent of a trend can be useful for managers. For instance, if few catchments encounter a decline of migratory fishes, it is likely that some causes of the decline are more related to local factors (e.g., management of the catchment). Conversely, if an overall decline is observed, the causes are probably related to more global factors (e.g., sea surface or river temperature warming, North Atlantic Oscillation).

The data used in this study (i.e., count data at monitoring stations) show a decrease in Alosa spp. and Petromyzon marinus counts at dates earlier than those found in other studies of populations in the same catchments but derived from fisheries catch data. These fisheries-independent monitoring networks therefore constitute an important complement to fisheries monitoring data, and can be used to provide early warnings of changes in populations.

In this study, we failed to highlight the effect of latitude on the change in fish counts (the most southern stations were not necessarily the ones with the populations most in decline and vice versa). Nevertheless, it would be interesting to analyse more precisely the link that could exist between the change in fish counts and the change in the major environmental parameters, in particular the temperature, which is often identified as the parameter responsible for the shifts in species distribution (e.g., Walther et al., 2002; Root et al., 2003; Chen et al., 2011; Williams and Blois, 2018). Moreover, the quantity of data collected in the STACOMI project is huge and should allow for other analyses that could be useful to understand better the population dynamics of these species. For instance, we analysed the change in Atlantic salmon counts without distinction of the sea age of the fish. Salmon sea age is an important driver in population dynamics, as it is related to the number and size of eggs produced by females $(e$. g., de Eyto et al., 2015; Glover et al., 2018). The data collected in STACOMI also include the date of passage of each fish. This information could be used to analyse the change in the phenology of migration over time. Indeed, numerous studies have documented a change in the phenology of migration of many taxa in response to recent warming (see Parmesan and Yohe, 2003). As diadromous fish have very constrained timing to achieve their life cycle, it would be very interesting to study the change in the timing of migration of these species over time.

Acknowledgments. We thank the following organizations for funding (in alphabetic order): Agence de l'eau Adour Garonne (AEAG), Agence de l'eau Loire-Bretagne (AELB), Agence de l'eau Rhin-Meuse (AERM), Agence de l'eau Seine-Normandie (AESN), Agence française pour la biodiversité (AFB-ONEMACSP), Conseil départemental du Bas-Rhin (CD67), Conseil départemental des Côtes d'Armor (CD22), Conseil départemental du Finistère (CD29), Conseil départemental d'Ille-etVilaine (CD35), Conseil départemental du Morbihan (CD56), Direction Régionale de l'Environnement Alsace (DREALDIREN), Direction Régionale de l'Environnement Bretagne 
(DREAL-DIREN), Electricité de France (EDF), European Regional Development Fund (FEDER), Federation départementale pour la pêche et la protection des milieux aquatiques du Bas-Rhin (FD67), Federation départementale pour la pêche et la protection des milieux aquatiques du Haut-Rhin (FD68), Fédération Nationale de la pêche en France (FNPF), Loire grands Migrateurs (LOGRAMI), Région Bretagne, Région Centre-Val de Loire, Région Grand Est, Région NouvelleAquitaine, Région Pays de la Loire, Saumon-Rhin. We thank the Muséum National d'Histoire Naturelle (MNHN) for their project management in carrying out some part of the monitoring in the Frémur River.

\section{References}

Aalto E, Capoccioni F, Terradez Mas J, et al. 2016. Quantifying 60 years of declining European eel (Anguilla anguilla L., 1758) fishery yields in Mediterranean coastal lagoons. ICES J Mar Sci 73: 101-110.

Acou A, Legault A, Laffaille P, Feunteun E. 2009. Environmental determinism of year-to-year recruitment variability of European eel Anguilla anguilla in a small coastal catchment, the Frémur River, north-west France. J Fish Biol 74: 1985-2001.

Akaike H. 1974. A new look at the statistical model identification. IEEE Trans Autom Control 19: 716-723.

Almeida PR, Quintella BR, Mateus CS, Alexandre CM, Pedro S. 2018. Diadromous fish in Portugal: status, threats and management guidelines. University of Algarve, Portugal, $28 \mathrm{p}$.

Anonyme. 2018. Plan de gestion anguille de la France - Rapport de mise en œuvre, France, 200 p.

Aprahamian MW, Baglinière J-L, Sabatié MR, Alexandrino P, Thiel R, Aprahamian CD. 2003. Biology, Status, and Conservation of the Anadromous Atlantic Twaite Shad Alosa fallax fallax. Am Fish Soc Symp 23.

Baglinière JL, Ellie P. 2000. Les aloses (Alosa alosa et Alosa fallax spp.). Paris, France: INRA-Cemagref edition, 275 p.

Baglinière J-L, Sabatié MR, Rochard E, Alexandrino P, Aprahamian MW. 2003. The allis shad Alosa alosa: Biology, ecology, range, and status of populations. Am Fish Soc Symp 2003: 85-102.

Baisez A, Bach J-M, Leon C, et al. 2011. Migration delays and mortality of adult Atlantic salmon Salmo salar en route to spawning grounds on the River Allier, France. Endang Spec Res 15: 265-270.

Bal G. 2011. Évolution des populations françaises de saumon atlantique (Salmo salar L.) et changement climatique. Université de Rennes 1, France, 352 p.

Barak NA-E, Mason CF. 1992. Population density, growth and diet of eels, Anguilla anguilla L., in two rivers in eastern England. Aquac Res 23: 59-70.

Barnosky AD, Matzke N, Tomiya S, et al. 2011. Has the Earth's sixth mass extinction already arrived? Nature 471: 51-57.

Beaulaton L, Taverny C, Castelnaud G. 2008. Fishing, abundance and life history traits of the anadromous sea lamprey (Petromyzon marinus) in Europe. Fish Res 92: 90-101.

Bergerot B, Cattanéo F. 2016. Hydrological drivers of brown trout population dynamics in France. Ecohydrology 1-15.

Bergstedt RA, Seelye JG. 1995. Evidence for Lack of Homing by Sea Lampreys. Trans Am Fish Soc 124: 235-239.

Blomqvist MM, Vos P, Klinkhamer PGL, ter Keurs WJ. 2003. Declining plant species richness of grassland ditch banks-a problem of colonisation or extinction? Biol Conserv 109: 391-406.
Bonhommeau S, Chassot E, Rivot E. 2008. Fluctuations in European eel (Anguilla anguilla) recruitment resulting from environmental changes in the Sargasso Sea. Fish Oceanogr 17: 32-44.

Borsuk ME, Reichert P, Peter A, Schager E, Burkhardt-Holm P. 2006. Assessing the decline of brown trout (Salmo trutta) in Swiss rivers using a Bayesian probability network. Ecol Model 192: 224-244.

Brett JR. 1967. Swimming Performance of Sockeye Salmon (Oncorhynchus nerka) in relation to Fatigue Time and Temperature. J Fish Res Board Canada 24: 1731-1741.

Briand, C. 2009. Dynamique de population et de migration des civelles en estuaire de Vilaine. Agrocampus Ouest, 205 p.

Briand C, Chapon PM, Beaulaton L, Drouineau H, Lambert P. 2018. Eel density analysis (EDA 2.2.1). Escapement of silver eels (Anguilla anguilla) from French rivers. EPTB Vilaine, AFB-INRA, IRSTEA, 99 p.

Briand C, Fatin D, Fontenelle G, Feunteun E. 2003. Estuarine and fluvial recruitment of the European glass eel, Anguilla anguilla, in an exploited Atlantic estuary. Fish Manag Ecol 10: 377-384.

Brodeur P, Mingelbier M, Bergeron N. 2007. Attractiveness and passage efficiency of two vertical slot fishways for non-salmonids in a temperate system, St. Lawrence River, Canada.

Brun M. 2011. Aide à la décision pour la conservation des populations de saumon atlantique (Salmo salar L.), Pau, 252 p.

Bryan MB, Zalinski D, Filcek KB, Libants S, Li W, Scribner KT. 2005. Patterns of invasion and colonization of the sea lamprey (Petromyzon marinus) in North America as revealed by microsatellite genotypes. Mol Ecol 14: 3757-3773.

Buisson L, Thuiller W, Lek S, Lim P, Grenouillet G. 2008. Climate change hastens the turnover of stream fish assemblages. Glob Change Biol 14: 2232-2248.

Butchart SHM, Walpole M, Collen B, et al. 2010. Global Biodiversity: Indicators of Recent Declines. Science 328: 1164-1168.

Caro T. 2008. Decline of large mammals in the Katavi-Rukwa ecosystem of western Tanzania. Afr Zool 43: 99-116.

Ceballos G, Ehrlich PR, Dirzo R. 2017. Biological annihilation via the ongoing sixth mass extinction signaled by vertebrate population losses and declines. PNAS 114: 6089-6096.

Chaput G. 2012. Overview of the status of Atlantic salmon (Salmo salar) in the North Atlantic and trends in marine mortality. ICES J Mar Sci 69: 1538-1548.

Chen I-C, Hill JK, Ohlemüller R, Roy DB, Thomas CD. 2011. Rapid Range Shifts of Species Associated with High Levels of Climate Warming. Science 333: 1024-1026.

Clausen R, York R. 2008. Global biodiversity decline of marine and freshwater fish: A cross-national analysis of economic, demographic, and ecological influences. Soc Sci Res 37: 1310-1320.

Clavero M, Brotons L, Pons P, Sol D. 2009. Prominent role of invasive species in avian biodiversity loss. Biol Conserv 142: 2043-2049.

Cloern JE, Abreu PC, Carstensen J, et al. 2016. Human activities and climate variability drive fast-paced change across the world's estuarine-coastal ecosystems. Glob Change Biol 22: 513-529.

Coll M, Carreras M, Cornax MJ, et al. 2014. Closer to reality: Reconstructing total removals in mixed fisheries from Southern Europe. Fish Res 154: 179-194.

Collen B, Whitton F, Dyer EE, et al. 2014. Global patterns of freshwater species diversity, threat and endemism. Glob Ecol Biogeogr 23: 40-51.

Comte L, Grenouillet G. 2015. Distribution shifts of freshwater fish under a variable climate: comparing climatic, bioclimatic and biotic velocities. Divers Distrib 21: 1014-1026. 
Culp LA, Cohen EB, Scarpignato AL, Thogmartin WE, Marra PP. 2017. Full annual cycle climate change vulnerability assessment for migratory birds. Ecosphere 8: 1-22.

Dannewitz J, Maes GE, Johansson L, Wickström H, Volckaert FAM, Järvi T. 2005. Panmixia in the European eel: a matter of time. Proc Roy Soc Biol Sci 272: 1129-1137.

Daufresne M, Boët P. 2007. Climate change impacts on structure and diversity of fish communities in rivers. Glob Change Biol 13: 2467-2478.

Dawson TP, Jackson ST, House JI, Prentice IC, Mace GM. 2011. Beyond predictions: biodiversity Conservation in a Changing Climate. Science 332: 53-58.

De Eyto E, Dalton C, Dillane M, et al. 2016. The response of North Atlantic diadromous fish to multiple stressors, including land use change: a multidecadal study. Can J Fish Aquat Sci 73: 1759-1769.

De Eyto E, White J, Boylan P, et al. 2015. The fecundity of wild Irish Atlantic salmon Salmo salar L. and its application for stock assessment purposes. Fish Res 164: 159-169.

Dekker W. 2000. Fractal geometry of the European eel stock. ICES J Mar Sci 57: 109-121.

Dekker W. 2003a. A conceptual management framework for the restoration of the declining european eel stock. In: Slipping through our hands - Population dynamics of the European eel, $188 \mathrm{p}$.

Dekker W. 2003b. Did lack of spawners cause the collapse of the European eel, Anguilla anguilla? Fish Manag Ecol 10: 365-376.

Dirzo R, Young HS, Galetti M, Ceballos G, Isaac NJB, Collen B. 2014. Defaunation in the Anthropocene. Science 345: 401-406.

Dumas J, Prouzet P. 1994. Repeuplement et pacage marin. In: Guegen JC and Prouzet P, ed. Le saumon atlantique: Biologie et gestion de la ressource, Ifremer, Paris, 239-254.

Fenkes M, Shiels HA, Fitzpatrick JL, Nudds RL. 2016. The potential impacts of migratory difficulty, including warmer waters and altered flow conditions, on the reproductive success of salmonid fishes. Comp Biochem Physiol A 193: 11-21.

Freyhof J, Brooks E. 2011. European red list of freshwater fishes. Luxembourg: Publications Office of the European Union, $70 \mathrm{p}$.

Frissell CA. 1993. Topology of Extinction and Endangerment of Native Fishes in the Pacific Northwest and California. Conserv Biol 7: $342-354$.

Gascuel D. 1986. Flow-carried and active swimming migration of the glass eel (Anguilla anguilla) in the tidal area of a small estuary on the French Atlantic coast. Helgolander Meeresunters 40: 321-326.

Glover RS, Fryer RJ, Bacon PJ, Soulsby C, Malcolm IA. 2018. Do trends in the size of wild female Atlantic salmon have a substantial effect on egg deposition? Fish Manag Ecol 25: 158-161.

Goulmy F. 2016. Station de comptages piscicoles des Claies de Vire - Comptage des poissons grands migrateurs. Fédération Départementale des Associations Agréées pour la Pêche et la Protection du Milieu Aquatique de la Manche, France, 66 p.

Gozlan R, Karimov B, Zadereev E, Kuznetsova D, Brucet S. 2019. Status, trends, and future dynamics of freshwater ecosystems in Europe and Central Asia. Inland Waters: 1-17.

Grime JP. 2002. Declining plant diversity: empty niches or functional shifts? J Veg Sci 13: 457-460.

Haapasaari P, Karjalainen TP. 2010. Formalizing expert knowledge to compare alternative management plans: sociological perspective to the future management of Baltic salmon stocks. Mar Policy 34: 477-486.

Hallmann CA, Sorg M, Jongejans E, et al. 2017. More than 75 percent decline over 27 years in total flying insect biomass in protected areas. PLOS ONE 12: 1-21.

Hamed KH, Ramachandra Rao A. 1998. A modified Mann-Kendall trend test for autocorrelated data. J Hydrol 204: 182-196.
Haro A, Castro-Santos T, Noreika J, Odeh M. 2004. Swimming performance of upstream migrant fishes in open-channel flow: a new approach to predicting passage through velocity barriers. Can $J$ Fish Aquatic Sci 61: 1590-1601.

Harris G, Thirgood S, Hopcraft JGC, Cromsigt JPGM, Berger J. 2009. Global decline in aggregated migrations of large terrestrial mammals. Endang Spec Res 7: 55-76.

Hasselman DJ, Bradford RG, Bentzen P. 2010. Taking stock: defining populations of American shad (Alosa sapidissima) in Canada using neutral genetic markers. Can J Fish Aquat Sci 67: 1021-1039.

Heller NE, Zavaleta ES. 2009. Biodiversity management in the face of climate change: a review of 22 years of recommendations. Biol Conserv 142: 14-32.

Horreo JL, Griffiths AM, Machado-Schiaffino G, Stevens JR, GarciaVazquez E. 2018. Northern areas as refugia for temperate species under current climate warming: Atlantic salmon (Salmo salar L.) as a model in northern Europe. J Fish Biol 95: 304-310.

Hughes TP. 1994. Catastrophes, phase shifts, and large-scale degradation of a caribbean coral reef. Science 265: 1547-1551.

Ibbotson A, Smith J, Scarlett P, Aprhamian M. 2002. Colonisation of freshwater habitats by the European eel Anguilla anguilla. Freshw Biol 47: 1696-1706.

ICES. 2015. Report of the Joint EIFAAC/ICES/GFCM Working Group on Eel (WGEEL). Antalya, Turkey, 132 p.

ICES. 2018. Report of the Working Group on North Atlantic Salmon (WGNAS). Woods Hole, $386 \mathrm{p}$.

IPBES. 2019. Global assessment report on biodiversity and ecosystem services of the Intergovernmental Science- Policy Platform on Biodiversity and Ecosystem Services. E. S. Brondizio, J. Settele, S. Díaz, and H. T. Ngo (editors). Bonn, Germany: IPBES Secretariat.

Jolly MT, Aprahamian MW, Hawkins SJ, et al. 2012. Population genetic structure of protected allis shad (Alosa alosa) and twaite shad (Alosa fallax). Mar Biol 159: 675-687.

Jones GP, McCormick MI, Srinivasan M, Eagle JV. 2004. Coral decline threatens fish biodiversity in marine reserves. PNAS 101: 8251-8253.

Keefer ML, Caudill CC. 2014. Homing and straying by anadromous salmonids: a review of mechanisms and rates. Rev Fish Biol Fisheries 24: 333-368.

Kelhart MD. 2007. Declining amphibian populations: what is the next step? BioScience 57: 112-112.

Kettle AJ, Vøllestad LA, Wibig J. 2011. Where once the eel and the elephant were together: decline of the European eel because of changing hydrology in southwest Europe and northwest Africa? Fish Fish 12: 380-411.

King TL, Kalinowski ST, Schill WB, Spidle AP, Lubinski BA. 2001. Population structure of Atlantic salmon (Salmo salar L.): a rangewide perspective from microsatellite DNA variation. Mol Ecol 10: 807-821.

Kuczynski L, Chevalier M, Laffaille P, Legrand M, Grenouillet G. 2017. Indirect effect of temperature on fish population abundances through phenological changes. PLOS ONE 12: 1-13.

Laffaille P, Caraguel J-M, Legault A. 2007. Temporal patterns in the upstream migration of European glass eels (Anguilla anguilla) at the Couesnon estuarine dam. Estuarine. Coastal Shelf Sci 73: $81-90$.

Lambert P, Jatteau P, Paumier A, Carry L, Drouineau H. 2018. Allis shad adopts an efficient spawning tactic to optimise offspring survival. Environ Biol Fish 101: 315-326.

Lasne É, Laffaille P. 2008a. Analysis of distribution patterns of yellow European eels in the Loire catchment using logistic models based 
on presence-absence of different size-classes. Ecol Freshw Fish 17: $30-37$.

Lasne É, Laffaille P. 2008b. Assessing the freshwater distribution of yellow eel. Knowl Manag Aquatic Ecosyst 390-391: 1-11.

Lassalle G, Rochard E. 2009. Impact of twenty-first century climate change on diadromous fish spread over Europe, North Africa and the Middle East. Glob Change Biol 15: 1072-1089.

Legrand M, Briand C, Besse T. 2019. stacomiR: a common tool for monitoring fish migration. J Open Source Softw 4: 1-3.

Liermann H. 2001. Depensation: evidence, models and implications. Fish Fish 2: 33-58.

Limburg KE, Waldman JR. 2009. Dramatic Declines in North Atlantic Diadromous Fishes. BioScience 59: 955-965.

Lobón-Cerviá J. 2009. Why, when and how do fish populations decline, collapse and recover? The example of brown trout (Salmo trutta) in Rio Chaballos (northwestern Spain). Freshw Biol 54: 1149-1162.

Lucas MC, Baras E. 2000. Methods for studying spatial behaviour of freshwater fishes in the natural environment. Fish Fish 1: 283-316.

Maas-Hebner KG, Schreck C, Hughes RM, Yeakley JA, Molina N. 2016. Scientifically Defensible Fish Conservation and Recovery Plans: Addressing Diffuse Threats and Developing Rigorous Adaptive Management Plans. Fisheries 41: 276-85.

Maes GE, Volckaert FaM. 2002. Clinal genetic variation and isolation by distance in the European eel Anguilla anguilla (L.). Biol J Linn Soc 77: 509-521.

Maire A, Thierry E, Viechtbauer W, Daufresne M. 2019. Poleward shift in large-river fish communities detected with a novel metaanalysis framework. Freshw Biol 00: 1-14.

Martin J, Rougemont Q, Drouineau H, et al. 2015. Dispersal capacities of anadromous Allis shad population inferred from a coupled genetic and otolith approach. Can J Fish Aquat Sci 72: 991-1003.

Maunder MN, Sibert JR, Fonteneau A, Hampton J, Kleiber P, Harley SJ. 2006. Interpreting catch per unit effort data to assess the status of individual stocks and communities. ICES J Mar Sci 63: 1373-1385.

McDowall RM. 1997. The evolution of diadromy in fishes (revisited) and its place in phylogenetic analysis. Fish Biol Fish 7: 443-462.

McDowall RM. 2001. Anadromy and homing: two life-history traits with adaptive synergies in salmonid fishes? Fish Fish 2: 78-85.

McDowall RM. 2008. Diadromy, history and ecology: a question of scale. Hydrobiologia 602: 5-14.

Melvin GD, Dadswell MJ, Martin JD. 1986. Fidelity of American Shad, Alosa sapidissima (Gupeidae), to its River of Previous Spawning. Can J Fish Aquat Sci 43: 640-646.

Milner NJ, Elliott JM, Armstrong JD, Gardiner R, Welton JS, Ladle M. 2003. The natural control of salmon and trout populations in streams. Fish Res 62: 111-125.

Mota M, Rochard E, Antunes CA. 2016. Status of the Diadromous fish of the Iberian Peninsula: Past, present and trends. Limnetica 35: $1-18$.

Murphy GEP, Romanuk TN. 2014. A meta-analysis of declines in local species richness from human disturbances. Ecol Evol 4: 91-103.

Myers GS. 1949. Usage of Anadromous, Catadromous and Allied Terms for Migratory Fishes. Copeia 1949: 89-97.

Myers RA, Barrowman NJ, Hutchings JA, Rosenberg AA. 1995. Population dynamics of exploited fish stocks at low population levels. Oceanogr Literat Rev 269: 1106-1108.

Nachón DJ, Mota M, Autunes C, Servia MJ, Cobo F. 2015. Marine and continental distribution and dynamic of the early spawning migration of twaite shad (Alosa fallax (Lacépède, 1803)) and allis shad (Alosa alosa (Linnaeus, 1758)) in the north-west of the Iberian Peninsula. Mar Freshw Res 67: 1229-1240.
Nicola GG, Elvira B, Jonsson B, Ayllón D, Almodóvar A. 2018. Local and global climatic drivers of Atlantic salmon decline in southern Europe. Fish Res 198: 78-85.

Nieto A, Ralph GM, Comeros-Raynal MT, et al. 2015. European Red List of marine fishes. Luxembourg: Publications Office of the European Union, $90 \mathrm{p}$.

Nilsson S, Franzén M, Jönsson E. 2008. Long-term land-use changes and extinction of specialised butterflies. Insect Conserv Divers 1: 197-207.

Palm S, Dannewitz J, Prestegaard T, Wickström H. 2009. Panmixia in European eel revisited: no genetic difference between maturing adults from southern and northern Europe. Heredity 103: 82-89.

Parmesan C, Yohe G. 2003. A globally coherent fingerprint of climate change impacts across natural systems. Nature 421: 37-42.

Parrish DL, Behnke RJ, Gephard SR, McCormick SD, Reeves GH. 1998. Why aren't there more Atlantic salmon (Salmo salar)? Can J Fish Aquat Sci 55: 281-287.

Perrier C, Guyomard R, Bagliniere J-L., Nikolic N, Evanno G. 2013. Changes in the genetic structure of Atlantic salmon populations over four decades reveal substantial impacts of stocking and potential resiliency. Ecol Evol 3: 2334-2349.

Petersson E. 2015. Homing and Timing of Reproduction. In: Evolutionary Biology of the Atlantic Salmon. New York: Taylor \& Francis Group, 290 p.

Pimm SL, Raven P. 2000. Extinction by numbers. Nature 403: 843-845.

Piper A, Wright RM, Kemp PS. 2012. The influence of attraction flow on upstream passage of European eel (Anguilla anguilla) at intertidal barriers. Ecol Eng 44: 329-336.

Potts SG, Biesmeijer JC, Kremen C, Neumann P, Schweiger O, Kunin WE. 2010. Global pollinator declines: trends, impacts and drivers. Trends Ecol Evol 25: 345-353.

Poulet N, Beaulaton L, Dembski S. 2011. Time trends in fish populations in metropolitan France: insights from national monitoring data. J Fish Biol 79: 1436-1452.

Randon M, Daverat F, Bareille G, et al. 2018. Quantifying exchanges of Allis shads between river catchments by combining otolith microchemistry and abundance indices in a Bayesian model. ICES J Mar Sci 75: 9-21.

Reynolds JD, Dulvy NK, Goodwin NB, Hutchings JA. 2005. Biology of extinction risk in marine fishes. Proc Roy Soc Biol Sci 272: 2337-2344.

Rochette S, Rivot E, Morin J, Mackinson S, Riou P, Le Pape O. 2010. Effect of nursery habitat degradation on flatfish population: application to Solea solea in the Eastern Channel (Western Europe). J Sea Res 64: 34-44.

Romakkaniemi A, Perä I, Karlsson L, Jutila E, Carlsson U, Pakarinen T. 2003. Development of wild Atlantic salmon stocks in the rivers of the northern Baltic Sea in response to management measures. ICES J Mar Sci 60: 329-342.

Root TLP, Price JT, Hall KR, Schneider SH, Rosenzweig C, Pounds JA. 2003. Fingerprints of global warming on wild animals and plants. Nature 421: 57-60.

Rougier T, Lambert P, Drouineau H, et al. 2012. Collapse of allis shad, Alosa alosa, in the Gironde system (southwest France): environmental change, fishing mortality, or Allee effect? ICES J Mar Sci 69: 1802-1811.

Sommer T, Armor C, Baxter R, et al. 2007. The Collapse of Pelagic Fishes in the Upper San Francisco Estuary. Fisheries 32: 270-277.

Spice EK, Goodman DH, Reid SB, Docker MF. 2012. Neither philopatric nor panmictic: microsatellite and mtDNA evidence 
suggests lack of natal homing but limits to dispersal in Pacific lamprey. Mol Ecol 21: 2916-2930.

Stout JC, Morales CL. 2009. Ecological impacts of invasive alien species on bees. Apidologie 40: 388-409.

Sun G-Q. 2016. Mathematical modeling of population dynamics with Allee effect. Nonlinear Dyn 85: 1-12.

Thibault M. 1994. Aperçu historique sur l'évolution des captures et des stocks. In: Guegen JC, Prouzet P,ed. Le saumon atlantique: Biologie et gestion de la ressource, Ifremer, Paris, 175-184.

Vasilakopoulos P, Maravelias CD, Tserpes G. 2014. The Alarming Decline of Mediterranean Fish Stocks. Curr Biol 24: 1643-1648.

Van de Pol M, Wright J. 2009. A simple method for distinguishing within- versus between-subject effects using mixed models. Anim Behav 77: 753-758.

Van Rij J. 2016. Testing for significance. http://www.jacolienvanrij. com/itsadug/test.html

Van Rij J, Wieling M, Baayen R, van Rijn H. 2017. itsadug: Interpreting Time Series and Autocorrelated Data Using GAMMs. $\mathrm{R}$ package version 2.3.

Viechtbauer W. 2010. Conducting Meta-Analyses in R with the metafor Package. J Stat Softw 36: 1-48.

Wake DB. 1991. Declining amphibian populations. Science 253: 860.

Waldman J, Grunwald C, Wirgin I. 2008. Sea lamprey Petromyzon marinus: an exception to the rule of homing in anadromous fishes. Biol Lett 4: 659-662.

Waldman J, Wilson KA, Mather M, Snyder NP. 2016. A resilience approach can improve anadromous fish restoration. Fisheries 41: $116-126$.
Walther G-R, Post E, Convey P, et al. 2002. Ecological responses to recent climate change. Nature 416: 389-95.

Walther BD, Thorrold SR, Olney JE. 2008. Geochemical Signatures in Otoliths Record Natal Origins of American Shad. Trans Am Fish Soc 137: 57-69.

Watson RT. 2005. Turning science into policy: challenges and experiences from the science-policy interface. Philos Trans Royal Soc B 360: 471-477.

Williams JE, Blois JL. 2018. Range shifts in response to past and future climate change: can climate velocities and species' dispersal capabilities explain variation in mammalian range shifts? $J$ Biogeogr 45: 2175-2189.

Winfree R, Aguilar R, Vázquez DP, LeBuhn G, Aizen MA. 2009. A meta-analysis of bees' responses to anthropogenic disturbance. Ecology 90: 2068-2076.

Wirth T, Bernatchez L. 2003. Decline of North Atlantic eels: a fatal synergy? Proc Royal Soc London 270: 681-688.

Wolter C. 2015. Historic catches, abundance, and decline of Atlantic salmon Salmo salar in the River Elbe. Aquat Sci 77: 367-380.

Young HS, McCauley DJ, Galetti M, Dirzo R. 2016. Patterns, Causes, and Consequences of Anthropocene Defaunation. Annu Rev Ecol Evol Syst 47: 333-358.

Zeller D, Rossing P, Harper S, Persson L, Booth S, Pauly D. 2011. The Baltic Sea: estimates of total fisheries removals 1950-2007. Fish Res 108: 356-63.

Zimmerli S, Bernet D, Burkhardt-Holm P, et al. 2007. Assessment of fish health status in four Swiss rivers showing a decline of brown trout catches. Aquat Sci 69: 11-25.

Cite this article as: Legrand M, Briand C, Buisson L, Artur G, Azam D, Baisez A, Barracou D, Bourré N, Carry L, Caudal A-L, Charrier F, Corre J, Croguennec E, Der Mikaélian S, Josset Q, Le Gurun L, Schaeffer F, Laffaille P. 2020. Contrasting trends between species and catchments in diadromous fish counts over the last 30 years in France. Knowl. Manag. Aquat. Ecosyst., 421, 7. 


\section{Appendix 1}

See Table 2.

Table 2. Characteristics of the 43 monitoring stations. Num: the station identification number (see Fig. 1). Latitude is in ${ }^{\circ} \mathrm{N}$. Year: the counting period for each station. The last three columns describe: (F.) the presence of a commercial or recreational gear fishery in the river downstream of the monitoring station; (S.) the presence of a salmon stocking programme influencing the counting; and (EC.) an observed improvement in ecological continuity of the river over the study period. Based on expert opinion, ' $\mathrm{X}$ ' indicates that the factor may have influenced fish counts, while '-' indicates the factor was not present or was likely to have no influence.

\begin{tabular}{|c|c|c|c|c|c|c|c|c|}
\hline Num & Station name & River & Catchment & Latitude & Year & F. & S. & EC. \\
\hline 1 & $\mathrm{Eu}$ & Bresle & Bresle & 50.05048 & $1984-2016$ & $\mathrm{X}$ & - & - \\
\hline 2 & Breuil-en-Auge & Touques & Touques & 49.22833 & 2005-2015 & - & - & $\mathrm{X}$ \\
\hline 3 & Claies-de-Vire & Vire & Vire & 49.17829 & $2002-2015$ & - & - & $X$ \\
\hline 4 & May-sur-Orne & Orne & Orne & 49.10641 & 2004-2016 & - & - & $\mathrm{X}$ \\
\hline 5 & Iffezheim & Rhin & Rhin & 48.83252 & 2003-2015 & $X$ & $X$ & - \\
\hline 6 & Gambsheim & Rhin & Rhin & 48.68441 & $2006-2015$ & - & $\mathrm{X}$ & - \\
\hline 7 & Cérisel & Oir & Oir & 48.62772 & $1983-2016$ & - & - & - \\
\hline 8 & Pont es Omnes & Frémur & Frémur & 48.57771 & $1996-2016$ & - & - & - \\
\hline 9 & Bois Joli & Frémur & Frémur & 48.57273 & 1996-2016 & - & - & - \\
\hline 10 & Kerhamon & Elorn & Elorn & 48.46253 & $2007-2016$ & - & $X$ & - \\
\hline 11 & Moulin du Vivier & Loysance & Loysance & 48.44941 & $1996-2010$ & - & $\mathrm{X}$ & - \\
\hline 12 & Châteaulin & Aulne & Aulne & 48.19670 & $1999-2015$ & - & - & - \\
\hline 13 & Moulin Neuf & Pont l'Abbé & Pont l'Abbé & 47.88601 & $2002-2016$ & - & - & - \\
\hline 14 & Moulin des Princes & Scorff & Scorff & 47.83691 & $1993-2016$ & - & - & - \\
\hline 15 & Malon & Vilaine & Vilaine & 47.79868 & $1998-2008$ & - & - & - \\
\hline 16 & Arzal & Vilaine & Vilaine & 47.49942 & $1995-2016$ & $\mathrm{X}$ & - & - \\
\hline 17 & Boisse & Vendée & Sèvre niortaise & 46.44812 & $1994-2013$ & - & - & - \\
\hline 18 & Massigny & Vendée & Sèvre niortaise & 46.42023 & 1994-2007 & - & - & - \\
\hline 19 & Boule d'Or Cinq Abbés & 5 abbés & Sèvre niortaise & 46.38675 & $1994-2013$ & - & - & - \\
\hline 20 & Boule d'Or Vendée & Vendée & Sèvre niortaise & 46.38666 & $1994-2013$ & - & - & - \\
\hline 21 & Cinq Abbés & 5 abbés & Sèvre niortaise & 46.33184 & $1996-2017$ & $\mathrm{X}$ & - & - \\
\hline 22 & Contreboth de Vix & tidal barrier & Sèvre niortaise & 46.32360 & $1996-2011$ & $\mathrm{X}$ & - & - \\
\hline 23 & Marais Pin & Sèvre niortaise & Sèvre niortaise & 46.32353 & $2008-2017$ & - & - & - \\
\hline 24 & Enfreneaux & Sèvre niortaise & Sèvre niortaise & 46.31705 & $1994-2017$ & $\mathrm{X}$ & - & - \\
\hline 25 & Descartes & Creuse & Loire & 46.97526 & $2007-2017$ & $X$ & $X$ & $X$ \\
\hline 26 & Decize & Loire & Loire & 46.83825 & $1998-2017$ & $\mathrm{X}$ & $\mathrm{X}$ & $\mathrm{X}$ \\
\hline 27 & Châtellerault & Vienne & Loire & 46.81105 & 2004-2017 & $X$ & $X$ & $\mathrm{X}$ \\
\hline 28 & Gueugnon & Arroux & Loire & 46.60957 & 2006-2017 & - & $X$ & - \\
\hline 29 & Vichy & Allier & Loire & 46.14205 & $1997-2017$ & $\mathrm{X}$ & $\mathrm{X}$ & $\mathrm{X}$ \\
\hline 30 & Poutès & Allier & Loire & 44.94727 & $1986-2016$ & - & $\mathrm{X}$ & $\mathrm{X}$ \\
\hline 31 & Mauzac & Dordogne & Garonne-Dordogne & 44.85417 & 2004-2015 & - & $\mathrm{X}$ & $\mathrm{X}$ \\
\hline 32 & Tuilières & Dordogne & Garonne-Dordogne & 44.84494 & $1993-2015$ & $\mathrm{X}$ & $\mathrm{X}$ & $\mathrm{X}$ \\
\hline 33 & Golfech & Garonne & Garonne-Dordogne & 44.10992 & $1993-2015$ & $\mathrm{X}$ & $\mathrm{X}$ & $X$ \\
\hline 34 & Bazacle & Garonne & Garonne-Dordogne & 43.60405 & $1993-2015$ & - & $\mathrm{X}$ & $X$ \\
\hline 35 & Carbonne & Garonne & Garonne-Dordogne & 43.28901 & $2000-2015$ & - & $\mathrm{X}$ & - \\
\hline 36 & Uxondoa & Nivelle & Nivelle & 43.36123 & $1996-2017$ & $X$ & - & - \\
\hline 37 & Olha & Nivelle & Nivelle & 43.34460 & $1996-2017$ & $\mathrm{X}$ & - & - \\
\hline 38 & Sorde-l'Abbaye & Gave d'Oloron & Adour & 43.52852 & $1996-2012$ & $X$ & $\mathrm{X}$ & - \\
\hline 39 & Artix & Gave de Pau & Adour & 43.38589 & $2005-2016$ & $\mathrm{X}$ & $\mathrm{X}$ & $\mathrm{X}$ \\
\hline 40 & Guerlain & Gave d'Oloron & Adour & 43.25641 & $1996-2012$ & $\mathrm{X}$ & $\mathrm{X}$ & $\mathrm{X}$ \\
\hline 41 & Chéraute & Saison & Adour & 43.23729 & $1996-2014$ & $\mathrm{X}$ & $\mathrm{X}$ & - \\
\hline 42 & Soeix & Gave d'Aspe & Adour & 43.15991 & $1996-2017$ & $\mathrm{X}$ & $\mathrm{X}$ & $X$ \\
\hline 43 & Saint-Cricq & Gave d'Ossau & Adour & 43.10887 & 2002-2011 & $\mathrm{X}$ & $\mathrm{X}$ & $X$ \\
\hline
\end{tabular}




\section{Appendix 2 GAMM for Alosa spp.}

Change in fish counts $(\log ($ counts +1$))$ of Alosa spp. over the study period and for the 12 catchments with counts for this taxon. Catchments are ordered by latitude from north to south. Grey points represent predictions $+/-$ residuals. White curves are the predicted values of the model and grey ribbons the $95 \%$ confidence intervals. The model explains $85 \%$ of the observed deviance.

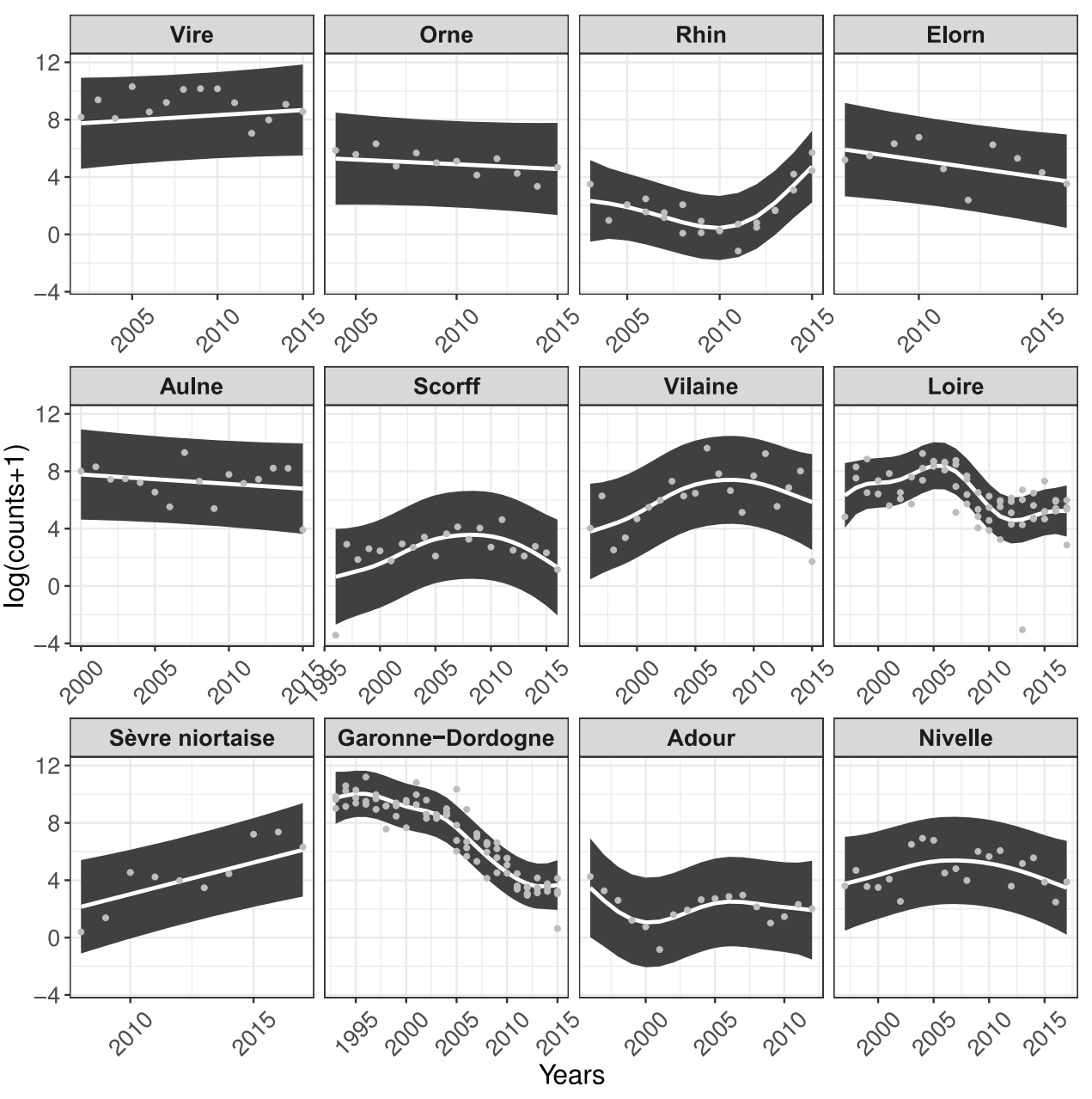




\section{Appendix 3 GAMM for Anguilla anguilla}

Change in fish counts $(\log ($ counts +1$))$ of Anguilla anguilla over the study period and for the 14 catchments with counts for this species. Catchments are ordered by latitude from north to south. Grey points represent predictions $+/-$ residuals. White curves are the predicted values of the model and grey ribbons the $95 \%$ confidence intervals. The model explains $87 \%$ of the observed deviance.

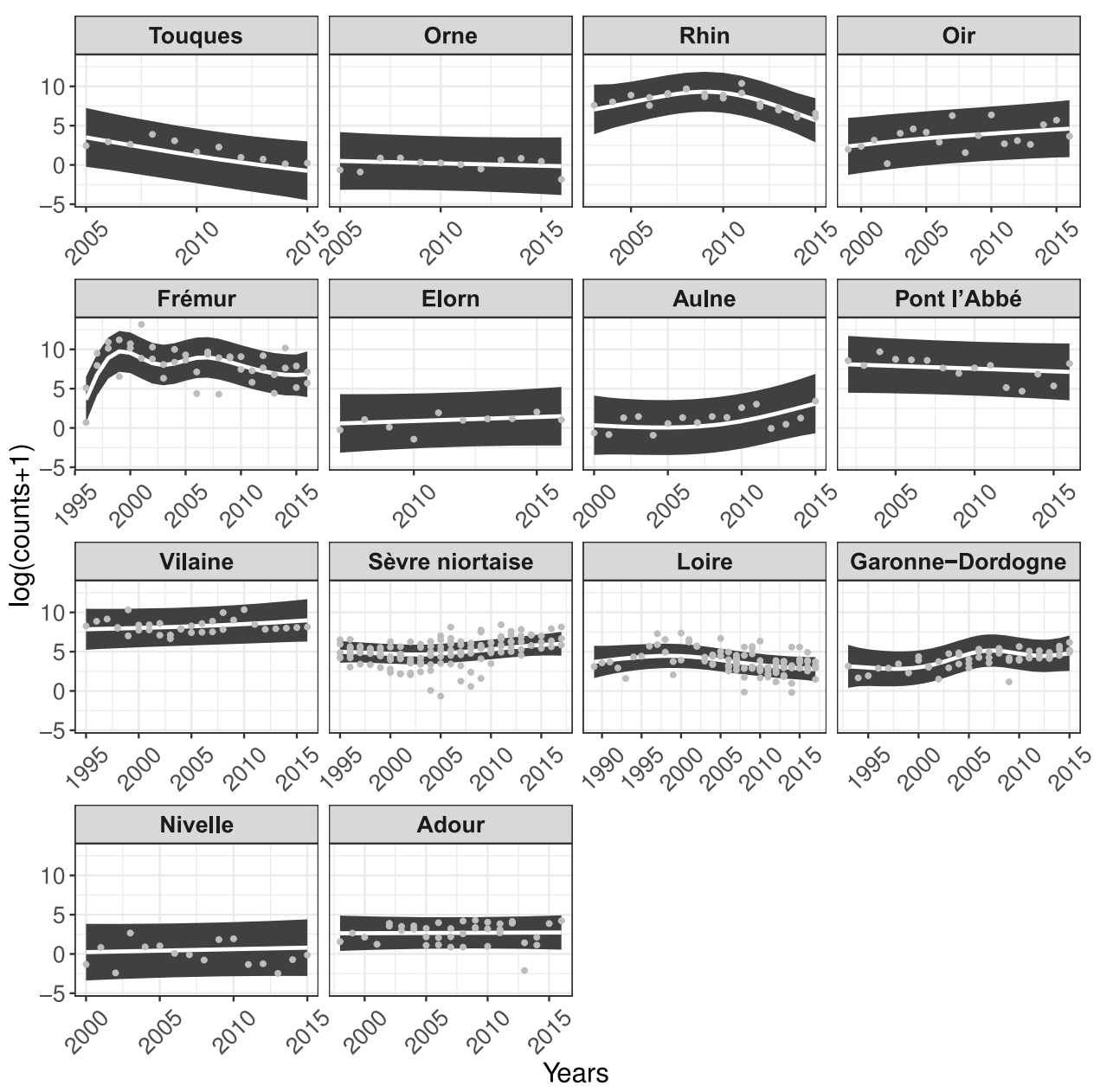




\section{Appendix 4 GAMM for Petromyzon marinus}

Change in fish counts $(\log ($ counts +1$))$ of Petromyzon marinus over the study period and for the 10 catchments with counts for this species. Catchments are ordered by latitude from north to south. Grey points represent predictions $+/-$ residuals. White curves are the predicted values of the model and grey ribbons the $95 \%$ confidence intervals. The model explains $73.7 \%$ of the observed deviance.
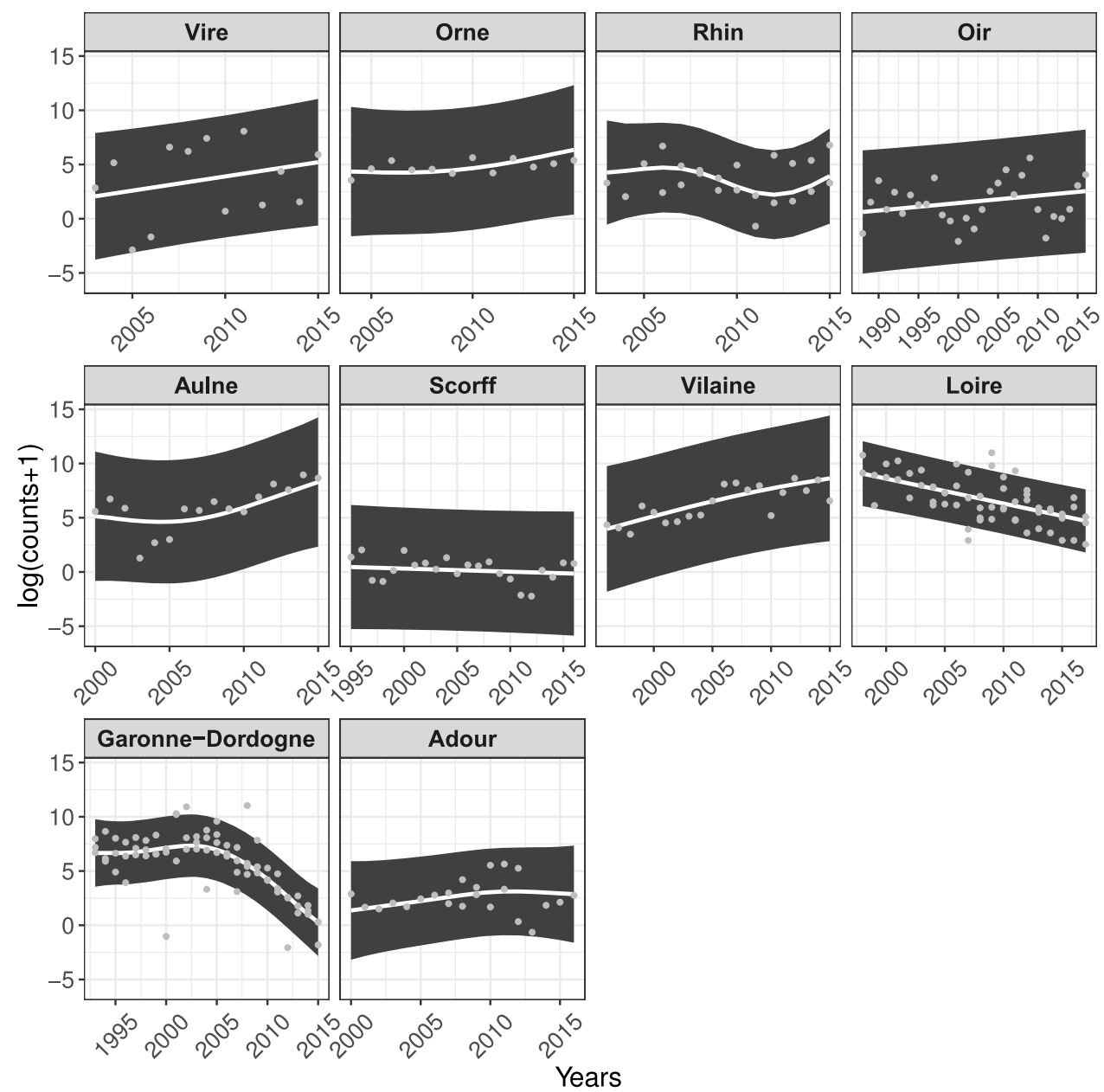


\section{Appendix 5 GAMM for Slamo salar}

Change in fish counts $(\log ($ counts +1$))$ of Salmo salar over the study period and for the 15 catchments with counts for this species. Catchments are ordered by latitude from north to south. Grey points represent predictions $+/-$ residuals. White curves are the predicted values of the model and grey ribbons the $95 \%$ confidence intervals. The model explains $79.1 \%$ of the observed deviance.

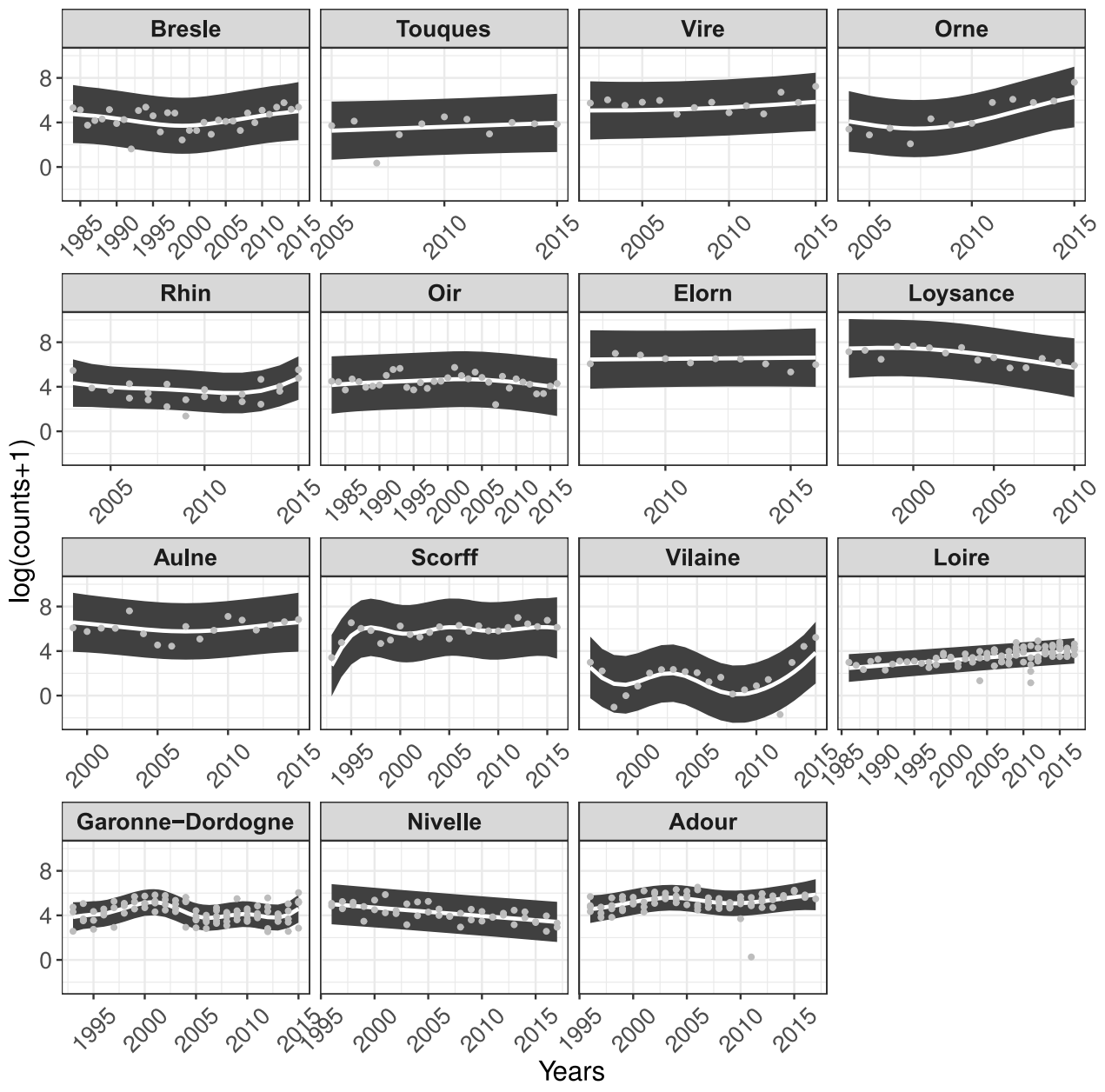




\section{Appendix 6 GAMM for Salmo trutta}

Change in fish counts $(\log ($ counts +1$))$ of Salmo trutta over the study period and for the 15 catchments with counts for this species. Catchments are ordered by latitude from north to south. Grey points represent predictions $+/-$ residuals. White curves are the predicted values of the model and grey ribbons the $95 \%$ confidence intervals. The model explains $87.9 \%$ of the observed deviance.

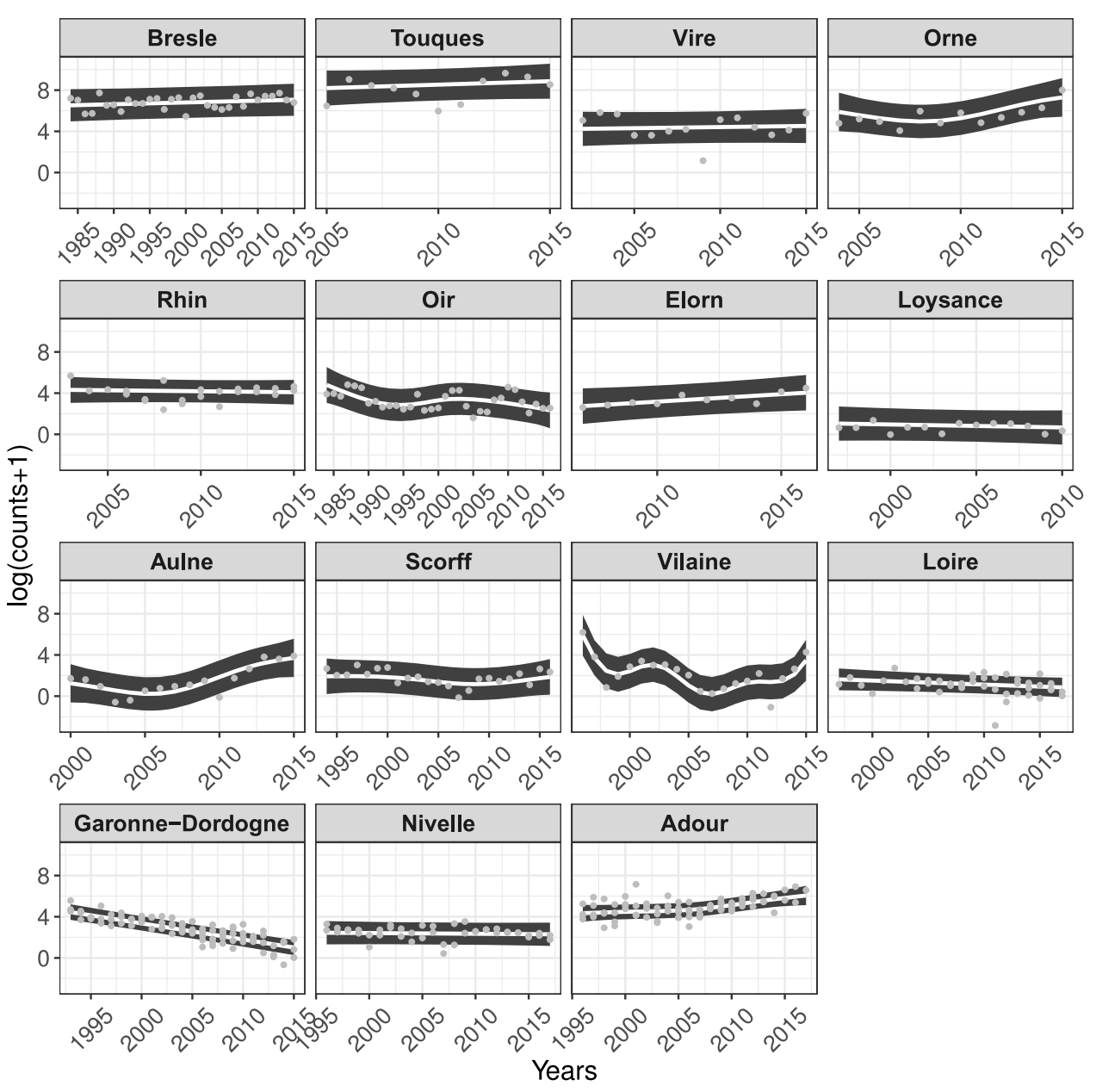

